Check for updates

Cite this: RSC Adv., 2020, 10, 12135

\title{
6,N2-Diaryl-1,3,5-triazine-2,4-diamines: synthesis, antiproliferative activity and 3D-QSAR modeling $\dagger$
}

\author{
Ahmad Junaid, ${ }^{a}$ Felicia Phei Lin Lim, (D) a Lay Hong Chuah ${ }^{a}$ \\ and Anton V. Dolzhenko (iD *ab
}

A library of 126 compounds with a 6,N $N^{2}$-diaryl-1,3,5-triazine-2,4-diamine scaffold was prepared using a one-pot, microwave-assisted method from readily available cyanoguanidine, aromatic aldehydes and arylamines. The three-component condensation of these reagents in the presence of hydrochloric acid was followed by the treatment with a base, which promoted a rearrangement of the dihydrotriazine ring and its dehydrogenative aromatization. The antiproliferative properties of the prepared compounds were evaluated using three breast cancer cell lines. The most promising results were obtained in the growth

Received 21st January 2020

Accepted 13th March 2020 inhibition of the triple negative MDA-MB231 breast cancer cells. The active compounds were also selective against cancer cells and did not affect growth of the non-cancerous MCF-10A breast cell line.

DOI: 10.1039/dOra00643b

rsc.li/rsc-advances Analyzing the structure-activity relationship within the series, we built a 3D-QSAR model for the further design of more potent anticancer compounds.

\section{Introduction}

The 1,3,5-triazine ring has been extensively explored as a scaffold for the design and construction of molecules with therapeutically useful properties. ${ }^{1}$ Particular advancements were made in the area of the anticancer agent development. ${ }^{2}$ Several 1,3,5-triazine based agents have been used for the treatment of various types of cancer, from earlier developed alkylating agents tretamine $e^{3,4}$ and altretamine ${ }^{5}$ to nucleic acid targeting nucleosides azacitidine ${ }^{6}$ and decitabine, ${ }^{7,8}$ and a recently approved inhibitor of isocitrate dehydrogenase 2, enasidenib ${ }^{9,10}$ (Fig. 1). An intensive exploration of the 1,3,5-triazine scaffold has continued and a number of notable anticancer 1,3,5-triazines have been recently developed, including those undergoing clinical trials gedatolisib inhibiting PI3K and mTOR kinases, ${ }^{11,12}$ PAK4 inhibitor KY-04031 effective against prostate cancer, ${ }^{13}$ and HL010183 particularly effective in the inhibition of proliferation and invasion of triple-negative breast cancer cells. ${ }^{14,15}$

Recently we reported a new effective synthesis of a library of 6, $N^{2}$-diaryl-1,3,5-triazine-2,4-diamines, some of which demonstrated promising anticancer properties in preliminary assessment on the DU145 prostate cancer cell line. ${ }^{16}$ Inspired by these

\footnotetext{
${ }^{a}$ School of Pharmacy, Monash University Malaysia, Jalan Lagoon Selatan, Bandar Sunway, Selangor Darul Ehsan 47500, Malaysia. E-mail: anton.dolzhenko@monash. edu

${ }^{b}$ School of Pharmacy and Biomedical Sciences, Curtin Health Innovation Research Institute, Faculty of Health Sciences, Curtin University, GPO Box U1987, Perth, Western Australia 6845, Australia

$\dagger$ Electronic supplementary information (ESI) available: Copies of ${ }^{1} \mathrm{H}$ and ${ }^{13} \mathrm{C}$ NMR spectra of new compounds and concentration-response plots used for the calculation $\mathrm{GI}_{50}$ values. See DOI: $10.1039 /$ d0ra00643b
}

results, we further expanded the initial library to 126 compounds and performed antiproliferative screening of these compounds on three types of breast cancer cell lines. Herein, we report result of this work and attempt to build a QSAR model for the further design of more active compounds.

\section{Results and discussion}

\section{Synthesis}

The microwave-assisted synthesis has been recognized as a highly valuable approach for the synthesis of 1,3,5-triazines. ${ }^{17}$ We applied focused microwave irradiation for the synthesis of 6, $N^{2}$-diaryl-1,3,5-triazine-2,4-diamines using a recently developed one-pot method. ${ }^{16}$ Initially, a three-component reaction of cyanoguanidine, aromatic aldehydes and arylamines was carried out in the presence of hydrochloric acid under microwave irradiation. Without isolation, intermediates I were treated with a base to give products of the Dimroth rearrangement II, which, at the reaction conditions, underwent a spontaneous dehydrogenation and aromatization affording desired 6, $N^{2}$-diaryl-1,3,5-triazine-2,4-diamines (1-126) (Scheme 1).

The developed protocol for the synthesis of $6, N^{2}$-diaryl-1,3,5triazine-2,4-diamines (1-126) was rather general and convenient for the generation of libraries covering a sufficiently broad chemical space for the biological screening.

\section{Cytotoxic evaluation}

The prepared compounds 1-126 were tested on three breast cancer cell lines namely, MDA-MB231, SKBR-3 and MCF-7 using MTT assay. SKBR-3 and MCF-7 cell lines are estrogen and progesterone hormone positive cell lines often used as a model 
<smiles></smiles>

Tretamine<smiles>Nc1ncn(C2OC(CO)C(O)C(O)C2O)c(=O)n1</smiles>

Azacitidine<smiles>Nc1ncn(C2CC(O)C(CO)O2)c(=O)n1</smiles>

Decitabine

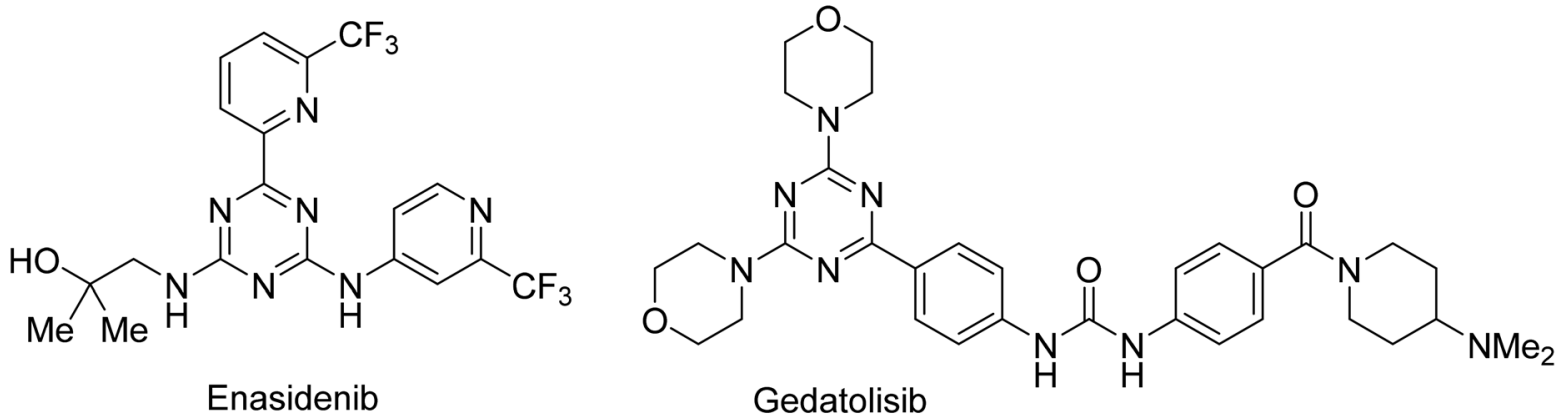<smiles>COc1nc(NCCc2c[nH]c3ccccc23)nc(Nc2ccc3[nH]ncc3c2)n1</smiles><smiles>CCCc1ccccc1Nc1nc(N)nc(N(C)C)n1</smiles>

HL010183

Fig. 1 Selected anticancer 1,3,5-triazines.

for the hormone therapy ${ }^{18}$ MDA-MB231 is triple negative breast cancer cell line, which is negative to estrogen and progesterone receptors and human epidermal growth factor receptor 2, a perfect model for chemotherapy. ${ }^{18}$ Initially, all the prepared compounds 1-126 were tested on these three cancer cell lines at the screening concentration $(10 \mu \mathrm{M})$ and percentage of cell viability was calculated $72 \mathrm{~h}$ after the treatment (Table 1 ).

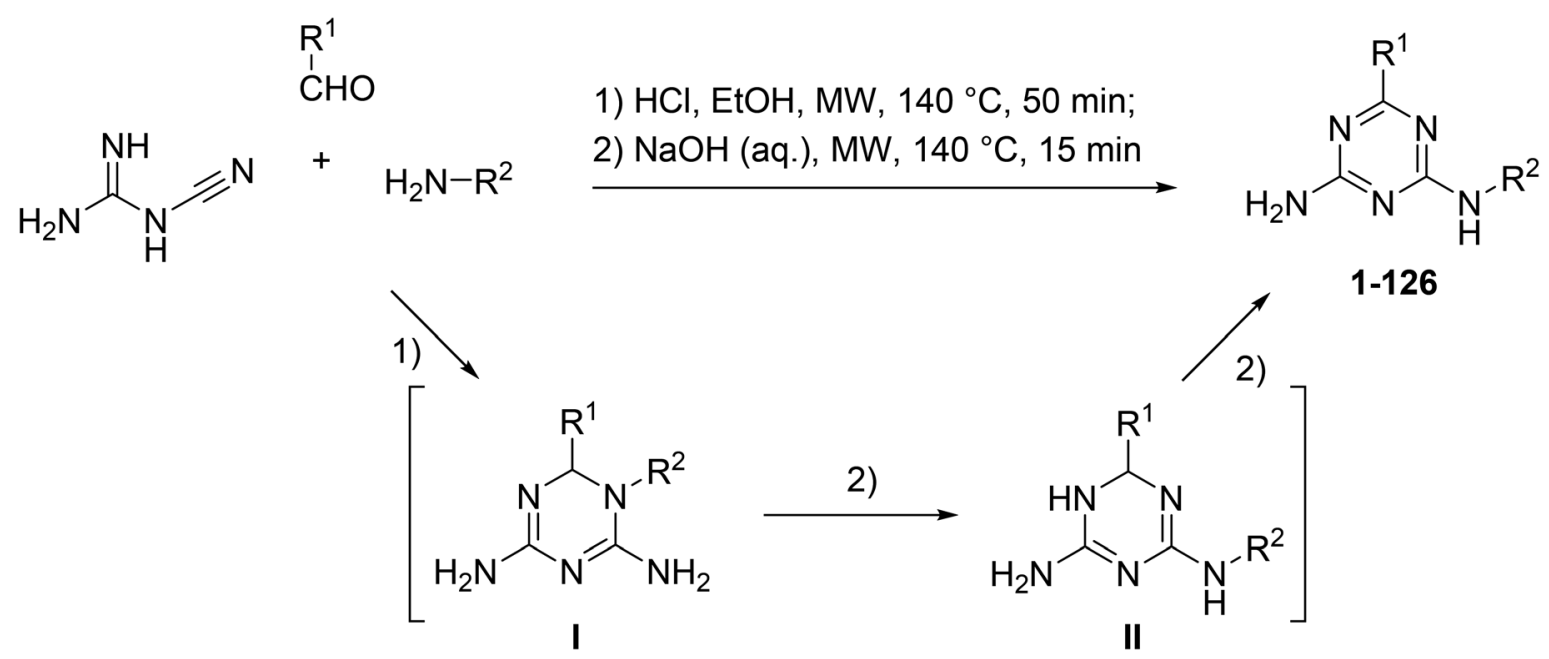

Scheme 1 Synthesis of 6,N $N^{2}$-diaryl-1,3,5-triazine-2,4-diamines (1-126). 
Table 1 Antiproliferative screening of $6, N^{2}$-diaryl-1,3,5-triazine-2,4diamines (1-126) at $10 \mu \mathrm{M}$<smiles>[R]Nc1nc([R])nc(N)n1</smiles>
Percentage of cell viability ${ }^{a}$

\begin{tabular}{|c|c|c|}
\hline Compd $\mathrm{R}^{1}$ & $\mathrm{R}^{2}$ & MDA-MB231 \\
\hline
\end{tabular}

\begin{tabular}{|c|c|c|c|c|c|}
\hline 1 & $\mathrm{Ph}$ & $\mathrm{Ph}$ & 87 & 81 & 90 \\
\hline 2 & $\mathrm{Ph}$ & $2-\mathrm{FC}_{6} \mathrm{H}_{4}$ & 82 & 83 & 99 \\
\hline 3 & $\mathrm{Ph}$ & $4-\mathrm{FC}_{6} \mathrm{H}_{4}$ & 81 & 84 & 100 \\
\hline 4 & $\mathrm{Ph}$ & $2-\mathrm{ClC}_{6} \mathrm{H}_{4}$ & 72 & 88 & 81 \\
\hline 5 & $\mathrm{Ph}$ & $4-\mathrm{ClC}_{6} \mathrm{H}_{4}$ & 65 & 94 & 100 \\
\hline 6 & $\mathrm{Ph}$ & $4-\mathrm{BrC}_{6} \mathrm{H}_{4}$ & 65 & 97 & 100 \\
\hline 7 & $\mathrm{Ph}$ & $4-\mathrm{MeC}_{6} \mathrm{H}_{4}$ & 98 & 87 & 87 \\
\hline 8 & $\mathrm{Ph}$ & $2-\mathrm{MeOC}_{6} \mathrm{H}_{4}$ & 78 & 97 & 91 \\
\hline 9 & $\mathrm{Ph}$ & $4-\mathrm{MeOC}_{6} \mathrm{H}_{4}$ & 98 & 96 & 84 \\
\hline 10 & $\mathrm{Ph}$ & $4-\mathrm{CF}_{3} \mathrm{OC}_{6} \mathrm{H}_{4}$ & 96 & 86 & 92 \\
\hline 11 & $\mathrm{Ph}$ & $4-\mathrm{iPrC}_{6} \mathrm{H}_{4}$ & 99 & 86 & 99 \\
\hline 12 & $\mathrm{Ph}$ & 3-Pyridyl & 59 & 78 & 87 \\
\hline 13 & $3-\mathrm{FC}_{6} \mathrm{H}_{4}$ & $\mathrm{Ph}$ & 100 & 100 & 89 \\
\hline 14 & $3-\mathrm{FC}_{6} \mathrm{H}_{4}$ & $4-\mathrm{FC}_{6} \mathrm{H}_{4}$ & 50 & 100 & 78 \\
\hline 15 & $3-\mathrm{FC}_{6} \mathrm{H}_{4}$ & $4-\mathrm{ClC}_{6} \mathrm{H}_{4}$ & 100 & 100 & 89 \\
\hline 16 & $3-\mathrm{FC}_{6} \mathrm{H}_{4}$ & $4-\mathrm{BrC}_{6} \mathrm{H}_{4}$ & 43 & 89 & 80 \\
\hline 17 & $3-\mathrm{FC}_{6} \mathrm{H}_{4}$ & $4-\mathrm{MeC}_{6} \mathrm{H}_{4}$ & 29 & 90 & 71 \\
\hline 18 & $3-\mathrm{FC}_{6} \mathrm{H}_{4}$ & $4-\mathrm{MeOC}_{6} \mathrm{H}_{4}$ & 46 & 74 & 76 \\
\hline 19 & $3-\mathrm{FC}_{6} \mathrm{H}_{4}$ & $4-\mathrm{CF}_{3} \mathrm{OC}_{6} \mathrm{H}_{4}$ & 50 & 100 & 76 \\
\hline 20 & $3-\mathrm{FC}_{6} \mathrm{H}_{4}$ & $4-\mathrm{iPrC}_{6} \mathrm{H}_{4}$ & 100 & 100 & 92 \\
\hline 21 & $4-\mathrm{FC}_{6} \mathrm{H}_{4}$ & $\mathrm{Ph}$ & 83 & 94 & 100 \\
\hline 22 & $4-\mathrm{FC}_{6} \mathrm{H}_{4}$ & $2-\mathrm{FC}_{6} \mathrm{H}_{4}$ & 83 & 85 & 100 \\
\hline 23 & $4-\mathrm{FC}_{6} \mathrm{H}_{4}$ & $4-\mathrm{FC}_{6} \mathrm{H}_{4}$ & 81 & 100 & 93 \\
\hline 24 & $4-\mathrm{FC}_{6} \mathrm{H}_{4}$ & $2-\mathrm{ClC}_{6} \mathrm{H}_{4}$ & 75 & 75 & 91 \\
\hline 25 & $4-\mathrm{FC}_{6} \mathrm{H}_{4}$ & $3-\mathrm{ClC}_{6} \mathrm{H}_{4}$ & 73 & 88 & 95 \\
\hline 26 & $4-\mathrm{FC}_{6} \mathrm{H}_{4}$ & $4-\mathrm{ClC}_{6} \mathrm{H}_{4}$ & 67 & 98 & 87 \\
\hline 27 & $4-\mathrm{FC}_{6} \mathrm{H}_{4}$ & $4-\mathrm{BrC}_{6} \mathrm{H}_{4}$ & 96 & 100 & 94 \\
\hline 28 & $4-\mathrm{FC}_{6} \mathrm{H}_{4}$ & $4-\mathrm{MeC}_{6} \mathrm{H}_{4}$ & 99 & 90 & 88 \\
\hline 29 & $4-\mathrm{FC}_{6} \mathrm{H}_{4}$ & $2-\mathrm{MeOC}_{6} \mathrm{H}_{4}$ & 60 & 81 & 96 \\
\hline 30 & $4-\mathrm{FC}_{6} \mathrm{H}_{4}$ & $4-\mathrm{MeOC}_{6} \mathrm{H}_{4}$ & 74 & 90 & 92 \\
\hline 31 & $4-\mathrm{FC}_{6} \mathrm{H}_{4}$ & $4-\mathrm{CF}_{3} \mathrm{OC}_{6} \mathrm{H}_{4}$ & 88 & 92 & 87 \\
\hline 32 & $4-\mathrm{FC}_{6} \mathrm{H}_{4}$ & $4-\mathrm{iPrC}_{6} \mathrm{H}_{4}$ & 94 & 100 & 84 \\
\hline 33 & $4-\mathrm{FC}_{6} \mathrm{H}_{4}$ & 3-Pyridyl & 74 & 87 & 85 \\
\hline 34 & $4-\mathrm{ClC}_{6} \mathrm{H}_{4}$ & $\mathrm{Ph}$ & 81 & 100 & 100 \\
\hline 35 & $4-\mathrm{ClC}_{6} \mathrm{H}_{4}$ & $2-\mathrm{FC}_{6} \mathrm{H}_{4}$ & 82 & 99 & 93 \\
\hline 36 & $4-\mathrm{ClC}_{6} \mathrm{H}_{4}$ & $4-\mathrm{FC}_{6} \mathrm{H}_{4}$ & 49 & 98 & 100 \\
\hline 37 & $4-\mathrm{ClC}_{6} \mathrm{H}_{4}$ & $2-\mathrm{ClC}_{6} \mathrm{H}_{4}$ & 99 & 89 & 99 \\
\hline 38 & $4-\mathrm{ClC}_{6} \mathrm{H}_{4}$ & $3-\mathrm{ClC}_{6} \mathrm{H}_{4}$ & 99 & 92 & 84 \\
\hline 39 & $4-\mathrm{ClC}_{6} \mathrm{H}_{4}$ & $4-\mathrm{ClC}_{6} \mathrm{H}_{4}$ & 97 & 100 & 100 \\
\hline 40 & $4-\mathrm{ClC}_{6} \mathrm{H}_{4}$ & $4-\mathrm{BrC}_{6} \mathrm{H}_{4}$ & 80 & 100 & 92 \\
\hline 41 & $4-\mathrm{ClC}_{6} \mathrm{H}_{4}$ & $2-\mathrm{MeOC}_{6} \mathrm{H}_{4}$ & 83 & 89 & 100 \\
\hline 42 & $4-\mathrm{ClC}_{6} \mathrm{H}_{4}$ & $4-\mathrm{MeOC}_{6} \mathrm{H}_{4}$ & 61 & 90 & 85 \\
\hline 43 & $4-\mathrm{ClC}_{6} \mathrm{H}_{4}$ & $4-\mathrm{CF}_{3} \mathrm{OC}_{6} \mathrm{H}_{4}$ & 93 & 83 & 100 \\
\hline 44 & $4-\mathrm{ClC}_{6} \mathrm{H}_{4}$ & $4-\mathrm{iPrC}_{6} \mathrm{H}_{4}$ & 100 & 97 & 96 \\
\hline 45 & $4-\mathrm{ClC}_{6} \mathrm{H}_{4}$ & 3-Pyridyl & 99 & 74 & 89 \\
\hline 46 & $4-\mathrm{BrC}_{6} \mathrm{H}_{4}$ & $2-\mathrm{FC}_{6} \mathrm{H}_{4}$ & 75 & 91 & 100 \\
\hline 47 & $4-\mathrm{BrC}_{6} \mathrm{H}_{4}$ & $4-\mathrm{FC}_{6} \mathrm{H}_{4}$ & 58 & 98 & 100 \\
\hline 48 & $4-\mathrm{BrC}_{6} \mathrm{H}_{4}$ & $2-\mathrm{ClC}_{6} \mathrm{H}_{4}$ & 90 & 93 & 100 \\
\hline 49 & $4-\mathrm{BrC}_{6} \mathrm{H}_{4}$ & $4-\mathrm{ClC}_{6} \mathrm{H}_{4}$ & 96 & 100 & 100 \\
\hline 50 & $4-\mathrm{BrC}_{6} \mathrm{H}_{4}$ & $4-\mathrm{MeC}_{6} \mathrm{H}_{4}$ & 55 & 93 & 88 \\
\hline 51 & $4-\mathrm{BrC}_{6} \mathrm{H}_{4}$ & $2-\mathrm{MeOC}_{6} \mathrm{H}_{4}$ & 88 & 89 & 96 \\
\hline 52 & $4-\mathrm{BrC}_{6} \mathrm{H}_{4}$ & $4-\mathrm{MeOC}_{6} \mathrm{H}_{4}$ & 56 & 91 & 100 \\
\hline
\end{tabular}

Table 1 (Contd.)<smiles>[R]Nc1nc([R])nc(N)n1</smiles>

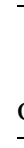

\begin{tabular}{|c|c|c|c|c|c|}
\hline \multirow[b]{2}{*}{ Compd } & \multirow[b]{2}{*}{$\mathrm{R}^{1}$} & \multirow[b]{2}{*}{$\mathrm{R}^{2}$} & \multicolumn{3}{|c|}{ Percentage of cell viability ${ }^{a}$} \\
\hline & & & MDA-MB231 & SKBR-3 & MCF-7 \\
\hline
\end{tabular}

$53 \quad 3-\mathrm{MeC}_{6} \mathrm{H}_{4} \quad 4-\mathrm{FC}_{6} \mathrm{H}_{4} \quad 100 \quad 100 \quad 78$

$54 \quad 3-\mathrm{MeC}_{6} \mathrm{H}_{4} \quad 4-\mathrm{ClC}_{6} \mathrm{H}_{4} \quad 100 \quad 93$

$55 \quad 3-\mathrm{MeC}_{6} \mathrm{H}_{4} \quad 4-\mathrm{BrC}_{6} \mathrm{H}_{4} \quad 83 \quad 96 \quad 75$

$56 \quad 3-\mathrm{MeC}_{6} \mathrm{H}_{4} \quad 4-\mathrm{MeC}_{6} \mathrm{H}_{4} \quad 12 \quad 62 \quad 67$

$57 \quad 3-\mathrm{MeC}_{6} \mathrm{H}_{4} \quad 4-\mathrm{MeOC}_{6} \mathrm{H}_{4} \quad 91 \quad 90 \quad 75$

$58 \quad 3-\mathrm{MeC}_{6} \mathrm{H}_{4} \quad 4-\mathrm{CF}_{3} \mathrm{OC}_{6} \mathrm{H}_{4} \quad 50 \quad 100 \quad 73$

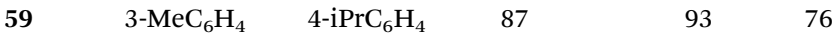

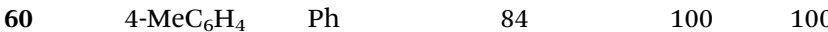

$61 \quad 4-\mathrm{MeC}_{6} \mathrm{H}_{4} \quad 2-\mathrm{FC}_{6} \mathrm{H}_{4} \quad 50 \quad 79$

$62 \quad 4-\mathrm{MeC}_{6} \mathrm{H}_{4} \quad 4-\mathrm{FC}_{6} \mathrm{H}_{4} \quad 48 \quad 78 \quad 100$

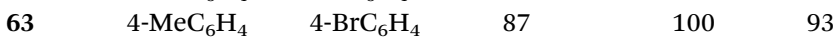

$64 \quad 4-\mathrm{MeC}_{6} \mathrm{H}_{4} \quad 4-\mathrm{MeC}_{6} \mathrm{H}_{4} \quad 59 \quad 92 \quad 86$

$654 \quad 4-\mathrm{MeC}_{6} \mathrm{H}_{4} \quad 2-\mathrm{MeOC}_{6} \mathrm{H}_{4} \quad 97 \quad 38$

$664 \quad 4-\mathrm{MeC}_{6} \mathrm{H}_{4} \quad 4-\mathrm{MeOC}_{6} \mathrm{H}_{4} \quad 83 \quad 89 \quad 100$

$67 \quad 4-\mathrm{MeC}_{6} \mathrm{H}_{4} \quad 4-\mathrm{CF}_{3} \mathrm{OC}_{6} \mathrm{H}_{4} \quad 92 \quad 03$

$684-\mathrm{MeC}_{6} \mathrm{H}_{4} \quad 4-\mathrm{iPrC}_{6} \mathrm{H}_{4} \quad 76 \quad 91$

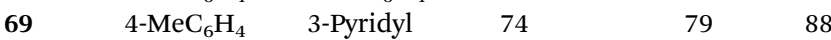

$704 \quad 4-\mathrm{MeOC}_{6} \mathrm{H}_{4} \quad 2-\mathrm{FC}_{6} \mathrm{H}_{4} \quad 9 \quad 63$

$71 \quad 4-\mathrm{MeOC}_{6} \mathrm{H}_{4} \quad 4-\mathrm{MeOC}_{6} \mathrm{H}_{4} \quad 56 \quad 93$

$72 \quad 4-\mathrm{MeOC}_{6} \mathrm{H}_{4} \quad 4-\mathrm{FC}_{6} \mathrm{H}_{4} \quad 68 \quad 100 \quad 100$

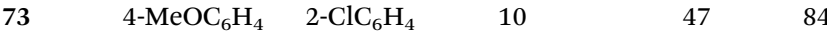

$74 \quad 4-\mathrm{MeOC}_{6} \mathrm{H}_{4} \quad 3-\mathrm{ClC}_{6} \mathrm{H}_{4} \quad 22 \quad 45$

$75 \quad 4-\mathrm{MeOC}_{6} \mathrm{H}_{4} \quad 4-\mathrm{ClC}_{6} \mathrm{H}_{4} \quad 99 \quad 100 \quad 100$

$76 \quad 4-\mathrm{MeOC}_{6} \mathrm{H}_{4} \quad 4-\mathrm{BrC}_{6} \mathrm{H}_{4} \quad 96 \quad 100$

$77 \quad 4-\mathrm{MeOC}_{6} \mathrm{H}_{4} \quad 3-\mathrm{MeC}_{6} \mathrm{H}_{4} \quad 22 \quad 40 \quad 79$

$78 \quad 4-\mathrm{MeOC}_{6} \mathrm{H}_{4} \quad 2-\mathrm{MeOC}_{6} \mathrm{H}_{4} \quad 50 \quad 66 \quad 57$

$794-\mathrm{MeOC}_{6} \mathrm{H}_{4} \quad 4-\mathrm{CF}_{3} \mathrm{OC}_{6} \mathrm{H}_{4} \quad 74 \quad 84$

$804-\mathrm{MeOC}_{6} \mathrm{H}_{4} \quad 4-\mathrm{iPrC}_{6} \mathrm{H}_{4} \quad 92$

814 4- $\mathrm{MeOC}_{6} \mathrm{H}_{4}$ 3-Pyridyl 46

$82 \quad 4-\mathrm{CF}_{3} \mathrm{C}_{6} \mathrm{H}_{4} \quad \mathrm{Ph} \quad 55$

$83 \quad 4-\mathrm{CF}_{3} \mathrm{C}_{6} \mathrm{H}_{4} \quad 2-\mathrm{FC}_{6} \mathrm{H}_{4} \quad 55$

$84 \quad 4-\mathrm{CF}_{3} \mathrm{C}_{6} \mathrm{H}_{4} \quad 4-\mathrm{FC}_{6} \mathrm{H}_{4} \quad 95$

$854-\mathrm{CF}_{3} \mathrm{C}_{6} \mathrm{H}_{4} \quad 4-\mathrm{ClC}_{6} \mathrm{H}_{4} \quad 90$

$86 \quad 4-\mathrm{CF}_{3} \mathrm{C}_{6} \mathrm{H}_{4} \quad 4-\mathrm{MeC}_{6} \mathrm{H}_{4} \quad 54$

$87 \quad 4-\mathrm{CF}_{3} \mathrm{C}_{6} \mathrm{H}_{4} \quad 2-\mathrm{MeOC}_{6} \mathrm{H}_{4} \quad 63$

$884-\mathrm{CF}_{3} \mathrm{C}_{6} \mathrm{H}_{4} \quad 4-\mathrm{MeOC}_{6} \mathrm{H}_{4} \quad 81$

$8944-\mathrm{CF}_{3} \mathrm{OC}_{6} \mathrm{H}_{4} \quad \mathrm{Ph} \quad 59$

$90 \quad 4-\mathrm{CF}_{3} \mathrm{OC}_{6} \mathrm{H}_{4} \quad 2-\mathrm{FC}_{6} \mathrm{H}_{4} \quad 60$

$9144-\mathrm{CF}_{3} \mathrm{OC}_{6} \mathrm{H}_{4} \quad 4-\mathrm{FC}_{6} \mathrm{H}_{4} \quad 53$

$92 \quad 4-\mathrm{CF}_{3} \mathrm{OC}_{6} \mathrm{H}_{4} \quad 2-\mathrm{ClC}_{6} \mathrm{H}_{4} \quad 74$

$934-\mathrm{CF}_{3} \mathrm{OC}_{6} \mathrm{H}_{4} \quad 4-\mathrm{BrC}_{6} \mathrm{H}_{4} \quad 83$

$94 \quad 4-\mathrm{CF}_{3} \mathrm{OC}_{6} \mathrm{H}_{4} \quad 4-\mathrm{MeC}_{6} \mathrm{H}_{4} \quad 79$

$95 \quad 4-\mathrm{CF}_{3} \mathrm{OC}_{6} \mathrm{H}_{4} \quad 2-\mathrm{MeOC}_{6} \mathrm{H}_{4} \quad 46$

$964-\mathrm{CF}_{3} \mathrm{OC}_{6} \mathrm{H}_{4} \quad 4-\mathrm{MeOC}_{6} \mathrm{H}_{4} \quad 69$

$97 \quad 4-\mathrm{CF}_{3} \mathrm{OC}_{6} \mathrm{H}_{4} \quad 4-\mathrm{CF}_{3} \mathrm{OC}_{6} \mathrm{H}_{4} \quad 92$

$98 \quad 4-\mathrm{CF}_{3} \mathrm{OC}_{6} \mathrm{H}_{4} \quad 4-\mathrm{iPrC}_{6} \mathrm{H}_{4} \quad 100$

$99 \quad 4-\mathrm{CF}_{3} \mathrm{OC}_{6} \mathrm{H}_{4}$ 3-Pyridyl 33

$1004-\mathrm{Me}_{2} \mathrm{NC}_{6} \mathrm{H}_{4} \quad \mathrm{Ph}$

$1014-\mathrm{Me}_{2} \mathrm{NC}_{6} \mathrm{H}_{4} \quad 2-\mathrm{FC}_{6} \mathrm{H}_{4}$

$1024-\mathrm{Me}_{2} \mathrm{NC}_{6} \mathrm{H}_{4} \quad 4-\mathrm{FC}_{6} \mathrm{H}_{4} \quad 32$

$1034-\mathrm{Me}_{2} \mathrm{NC}_{6} \mathrm{H}_{4} \quad 2-\mathrm{MeOC}_{6} \mathrm{H}_{4} \quad 28$

104

$4-\mathrm{Me}_{2} \mathrm{NC}_{6} \mathrm{H}_{4} \quad 4-\mathrm{iPrC}_{6} \mathrm{H}_{4} \quad 70$

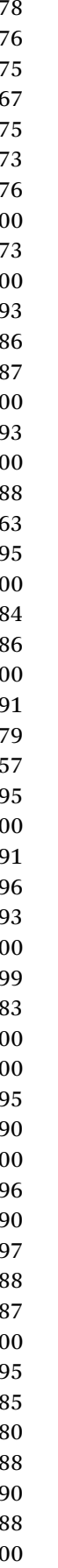


Table 1 (Contd.)<smiles>[R]Nc1nc([R])nc(N)n1</smiles>

\begin{tabular}{|c|c|c|c|c|c|}
\hline \multirow[b]{2}{*}{ Compd } & \multirow[b]{2}{*}{$\mathrm{R}^{1}$} & \multirow[b]{2}{*}{$\mathrm{R}^{2}$} & \multicolumn{3}{|c|}{ Percentage of cell viability ${ }^{a}$} \\
\hline & & & MDA-MB231 & SKBR-3 & MCF-7 \\
\hline 105 & $4-t \mathrm{BuC}_{6} \mathrm{H}_{4}$ & $\mathrm{Ph}$ & 74 & 100 & 96 \\
\hline 106 & $4-t \mathrm{BuC}_{6} \mathrm{H}_{4}$ & $4-\mathrm{FC}_{6} \mathrm{H}_{4}$ & 97 & 84 & 88 \\
\hline 107 & $4-t \mathrm{BuC}_{6} \mathrm{H}_{4}$ & $4-\mathrm{ClC}_{6} \mathrm{H}_{4}$ & 100 & 92 & 98 \\
\hline 108 & $4-t \mathrm{BuC}_{6} \mathrm{H}_{4}$ & $4-\mathrm{BrC}_{6} \mathrm{H}_{4}$ & 59 & 98 & 99 \\
\hline 109 & $4-t \mathrm{BuC}_{6} \mathrm{H}_{4}$ & $4-\mathrm{MeOC}_{6} \mathrm{H}_{4}$ & 91 & 85 & 93 \\
\hline 110 & $4-\mathrm{BnOC}_{6} \mathrm{H}_{4}$ & $\mathrm{Ph}$ & 51 & 75 & 100 \\
\hline 111 & $4-\mathrm{BnOC}_{6} \mathrm{H}_{4}$ & $4-\mathrm{FC}_{6} \mathrm{H}_{4}$ & 69 & 84 & 89 \\
\hline 112 & $4-\mathrm{BnOC}_{6} \mathrm{H}_{4}$ & $4-\mathrm{BrC}_{6} \mathrm{H}_{4}$ & 82 & 93 & 97 \\
\hline 113 & $4-\mathrm{BnOC}_{6} \mathrm{H}_{4}$ & $4-\mathrm{MeC}_{6} \mathrm{H}_{4}$ & 82 & 94 & 100 \\
\hline 114 & $4-\mathrm{BnOC}_{6} \mathrm{H}_{4}$ & $4-\mathrm{CF}_{3} \mathrm{OC}_{6} \mathrm{H}_{4}$ & 71 & 87 & 100 \\
\hline 115 & 2-Thienyl & $\mathrm{Ph}$ & 100 & 87 & 91 \\
\hline 116 & 2-Thienyl & $2-\mathrm{FC}_{6} \mathrm{H}_{4}$ & 98 & 78 & 90 \\
\hline 117 & 2-Thienyl & $4-\mathrm{FC}_{6} \mathrm{H}_{4}$ & 100 & 86 & 92 \\
\hline 118 & 2-Thienyl & $2-\mathrm{ClC}_{6} \mathrm{H}_{4}$ & 100 & 78 & 91 \\
\hline 119 & 2-Thienyl & $4-\mathrm{ClC}_{6} \mathrm{H}_{4}$ & 100 & 89 & 98 \\
\hline 120 & 2-Thienyl & $4-\mathrm{BrC}_{6} \mathrm{H}_{4}$ & 46 & 87 & 88 \\
\hline 121 & 2-Thienyl & $4-\mathrm{MeC}_{6} \mathrm{H}_{4}$ & 49 & 95 & 97 \\
\hline 122 & 2-Thienyl & $2-\mathrm{MeOC}_{6} \mathrm{H}_{4}$ & 78 & 97 & 91 \\
\hline 123 & 2-Thienyl & $4-\mathrm{MeOC}_{6} \mathrm{H}_{4}$ & 93 & 88 & 80 \\
\hline 124 & 2-Thienyl & $4-\mathrm{CF}_{3} \mathrm{OC}_{6} \mathrm{H}_{4}$ & 100 & 86 & 85 \\
\hline 125 & 2-Thienyl & $4-\mathrm{iPrC}_{6} \mathrm{H}_{4}$ & 100 & 86 & 89 \\
\hline 126 & 2-Thienyl & 3-Pyridyl & 100 & 91 & 86 \\
\hline
\end{tabular}

${ }^{a}$ Mean of three independent experiments.

The prepared 6, $N^{2}$-diaryl-1,3,5-triazine-2,4-diamines selectively inhibited the triple negative breast cancer cells. It was observed that hormone independent cell line (MDA-MB231) was generally more sensitive to the treatment with $6, N^{2}$-diaryl-1,3,5triazine-2,4-diamines, whereas hormone dependent cancer cell lines (SKBR-3 and MCF-7) were more resistant to the treatment with these compounds.

Compounds reducing the growth of the MDA-MB231 cancer cells (at concentration $10 \mu \mathrm{M}$ ) to $50 \%$ or less were selected for the evaluation of their $50 \%$ growth inhibitory concentrations $\left(\mathrm{GI}_{50}\right)$. The growth inhibitory effect of the compounds was determined on breast tumor cell line (MDA-MB231, SKBR-3 and MCF-7) at different concentrations with methotrexate and nilotinib as positive controls (Table 2). All the tested compounds were more effective towards the MDA-MB231 cancer cell line than SKBR-3 and MCF-7 cells.

Analysis of the structure-activity relationship identified a pattern in types and combinations of $\mathrm{R}^{1}$ and $\mathrm{R}^{2}$ groups associated with the antiproliferative effect. In general, replacement of a phenyl at $\mathrm{R}^{1}$ with the 2-thienyl moiety or a phenyl at $\mathrm{R}^{2}$ with the 3-pyridyl ring demonstrated only slight or no improvement in the cell growth inhibition. Analyzing effect of the substituent at the phenyl rings, we found that antiproliferative properties typically required $+\mathrm{M}$ electron-donating groups in para-position of the $\mathrm{R}^{1}$ phenyl ring or a meta-substitution in the same ring. The tolerance of the activity to the $\mathrm{R}^{2}$ substituents depended on the type of the $\mathrm{R}^{1}$ substitution. The combination of a para-substituted phenyl as $\mathrm{R}^{1}$ with the para-substituted phenyl as $\mathrm{R}^{2}$ was detrimental for the activity (except $\mathrm{R}^{2}=4-\mathrm{FC}_{6} \mathrm{H}_{4}$ ). However, the antiproliferative effect of compounds with a meta-substituted phenyl as $\mathrm{R}^{1}$ was less sensitive to the position of substituents in the $\mathrm{R}^{2}$ moiety. These compounds retained good antiproliferative effect with the para-substituted phenyl as the $\mathrm{R}^{2}$ group. The most efficient for the antiproliferative activity against MDA-MB231 cells were combinations of para-methoxy or para-dimethylamino groups in the $\mathrm{R}^{1}$ phenyl ring and ortho-fluoro- or ortho-chlorophenyl group as $\mathrm{R}^{2}$ (compounds 70, 73, and 101). These compounds were also very active against SKBR-3 cells. Moreover, compound 73 was equipotent in the inhibition of MDA-MB231 and SKBR-3 cell growth. Compound $\mathbf{1 0 1}$ was identified as the most active among the tested compounds in its cytotoxic effect against MDA-MB231 cells with $\mathrm{GI}_{50}$ value of $0.06 \mu \mathrm{M}$.

All the compounds, selected for determination of $\mathrm{GI}_{50}$ values against MDA-MB231 cells, were also used for the experiments with MCF-10A normal breast cells. None of the tested compounds applied at concentration of $25 \mu \mathrm{M}$ showed significant inhibition of the normal breast cell growth. These results indicated that the tested compounds were selectively active towards the breast cancer cells without any substantial effects on the normal breast cells.

\section{D-QSAR study}

To comprehend the structural requirement controlling the antiproliferative activity, a 3D-QSAR model was built applying 3D-QSAR protocol of Discovery Studio v18 (ref. 19) to the experimentally obtained biological data. Twenty-five compounds, having $\mathrm{GI}_{50}$ values against MDA-MB231 breast cancer cell line in the range of $0.06 \mu \mathrm{M}$ to $15.24 \mu \mathrm{M}$, were selected as model data set. The $\mathrm{GI}_{50}$ values of the compounds were converted into corresponding $\mathrm{pGI}_{50}$ values $\left(-\log \left[\mathrm{GI}_{50}\right]\right)$ using 'Prepare dependent values' protocol in Discovery Studio. The compounds were initially aligned to the minimum energy and then randomly divided into training set $(\sim 80 \%)$ and test set $(\sim 20 \%)$ by 'Diverse molecule' method in Discovery Studio.

The QSAR model was built using 'Create 3D-QSAR model' protocol in Discovery Studio. The correlation coefficient $r^{2}$ between the observed and predicted pGI $_{50}$ values of the training set was found to be 0.81 proving acceptability of the built QSAR model. RMSE residual error was found to be 0.31 indicating a good ability of the built model to predict the $\mathrm{GI}_{50}$ values. The $r^{2}$ value $>0.5$ and RMSE residual error $<0.5$ were considered to represent good model. ${ }^{20,21}$ Graphically, the model predictive potential is represented by the plot of the experimental $\mathrm{pGI}_{50}$ versus predicted $\mathrm{pGI}_{50}$ values (Fig. 2). The $\mathrm{pGI}_{50}$ values predicted by this QSAR model and the residual errors for all 25 compounds are presented in Table 3 . 
Table 2 Inhibition of cell growth by compounds selected after the initial screening<smiles>[R]Nc1nc([R])nc(N)n1</smiles>

\begin{tabular}{|c|c|c|c|c|c|c|}
\hline \multirow[b]{2}{*}{ Compound } & \multirow[b]{2}{*}{$\mathrm{R}^{1}$} & \multirow[b]{2}{*}{$\mathrm{R}^{2}$} & \multicolumn{4}{|c|}{$\mathrm{GI}_{50}{ }^{a}(\mu \mathrm{M}) \pm \mathrm{SEM}^{b}$} \\
\hline & & & MDA-MB231 & SKBR-3 & MCF-7 & MCF-10A \\
\hline 14 & $3-\mathrm{FC}_{6} \mathrm{H}_{4}$ & $4-\mathrm{FC}_{6} \mathrm{H}_{4}$ & $9.21 \pm 0.38$ & $>20$ & $>20$ & $>25$ \\
\hline 16 & $3-\mathrm{FC}_{6} \mathrm{H}_{4}$ & $4-\mathrm{BrC}_{6} \mathrm{H}_{4}$ & $13.13 \pm 0.91$ & $17.16 \pm 1.07$ & $>20$ & $>25$ \\
\hline 17 & $3-\mathrm{FC}_{6} \mathrm{H}_{4}$ & $4-\mathrm{MeC}_{6} \mathrm{H}_{4}$ & $3.96 \pm 0.17$ & $>20$ & $>20$ & $>25$ \\
\hline 18 & $3-\mathrm{FC}_{6} \mathrm{H}_{4}$ & $4-\mathrm{MeOC}_{6} \mathrm{H}_{4}$ & $6.18 \pm 0.43$ & $16.63 \pm 1.38$ & $>20$ & $>25$ \\
\hline 19 & $3-\mathrm{FC}_{6} \mathrm{H}_{4}$ & $4-\mathrm{CF}_{3} \mathrm{OC}_{6} \mathrm{H}_{4}$ & $8.56 \pm 0.59$ & $>20$ & $18.22 \pm 1.28$ & $>25$ \\
\hline 36 & $4-\mathrm{ClC}_{6} \mathrm{H}_{4}$ & $4-\mathrm{FC}_{6} \mathrm{H}_{4}$ & $14.14 \pm 1.52$ & $19.40 \pm 2.39$ & $>20$ & $>25$ \\
\hline 56 & $3-\mathrm{MeC}_{6} \mathrm{H}_{4}$ & $4-\mathrm{MeC}_{6} \mathrm{H}_{4}$ & $0.17 \pm 0.02$ & $1.26 \pm 0.18$ & $>20$ & $>25$ \\
\hline 58 & $3-\mathrm{MeC}_{6} \mathrm{H}_{4}$ & $4-\mathrm{CF}_{3} \mathrm{OC}_{6} \mathrm{H}_{4}$ & $15.24 \pm 1.01$ & $>20$ & $>20$ & $>25$ \\
\hline 61 & $4-\mathrm{MeC}_{6} \mathrm{H}_{4}$ & $2-\mathrm{FC}_{6} \mathrm{H}_{4}$ & $12.25 \pm 1.15$ & $>20$ & $>20$ & $>25$ \\
\hline 62 & $4-\mathrm{MeC}_{6} \mathrm{H}_{4}$ & $4-\mathrm{FC}_{6} \mathrm{H}_{4}$ & $10.68 \pm 0.73$ & $>20$ & $20.15 \pm 1.95$ & $>25$ \\
\hline 70 & $4-\mathrm{MeOC}_{6} \mathrm{H}_{4}$ & $2-\mathrm{FC}_{6} \mathrm{H}_{4}$ & $0.32 \pm 0.04$ & $>20$ & $>20$ & $>25$ \\
\hline 73 & $4-\mathrm{MeOC}_{6} \mathrm{H}_{4}$ & $2-\mathrm{ClC}_{6} \mathrm{H}_{4}$ & $0.23 \pm 0.03$ & $1.10 \pm 0.01$ & $>20$ & $>25$ \\
\hline 74 & $4-\mathrm{MeOC}_{6} \mathrm{H}_{4}$ & $3-\mathrm{ClC}_{6} \mathrm{H}_{4}$ & $1.33 \pm 0.17$ & $0.18 \pm 0.04$ & $18.30 \pm 1.11$ & $>25$ \\
\hline 77 & $4-\mathrm{MeOC}_{6} \mathrm{H}_{4}$ & $3-\mathrm{MeC}_{6} \mathrm{H}_{4}$ & $0.95 \pm 0.04$ & $3.38 \pm 0.36$ & $>20$ & $>25$ \\
\hline 78 & $4-\mathrm{MeOC}_{6} \mathrm{H}_{4}$ & $2-\mathrm{MeOC}_{6} \mathrm{H}_{4}$ & $13.25 \pm 0.93$ & $2.15 \pm 0.12$ & $>20$ & $>25$ \\
\hline 81 & $4-\mathrm{MeOC}_{6} \mathrm{H}_{4}$ & 3-Pyridyl & $14.01 \pm 1.33$ & $15.58 \pm 1.06$ & $>20$ & $>25$ \\
\hline 95 & $4-\mathrm{CF}_{3} \mathrm{OC}_{6} \mathrm{H}_{4}$ & $2-\mathrm{MeOC}_{6} \mathrm{H}_{4}$ & $12.77 \pm 0.76$ & $>20$ & $>20$ & $>25$ \\
\hline 99 & $4-\mathrm{CF}_{3} \mathrm{OC}_{6} \mathrm{H}_{4}$ & 3-Pyridyl & $11.52 \pm 1.51$ & $>20$ & $>20$ & $>25$ \\
\hline 100 & $4-\mathrm{Me}_{2} \mathrm{NC}_{6} \mathrm{H}_{4}$ & $\mathrm{Ph}$ & $0.36 \pm 0.07$ & $4.19 \pm 0.37$ & $>20$ & $>25$ \\
\hline 101 & $4-\mathrm{Me}_{2} \mathrm{NC}_{6} \mathrm{H}_{4}$ & 2- $-\mathrm{FC}_{6} \mathrm{H}_{4}$ & $0.06 \pm 0.001$ & $0.29 \pm 0.04$ & $>20$ & $>25$ \\
\hline 102 & $4-\mathrm{Me}_{2} \mathrm{NC}_{6} \mathrm{H}_{4}$ & 4- $-\mathrm{FC}_{6} \mathrm{H}_{4}$ & $7.20 \pm 0.94$ & $>20$ & $>20$ & $>25$ \\
\hline 103 & $4-\mathrm{Me}_{2} \mathrm{NC}_{6} \mathrm{H}_{4}$ & $2-\mathrm{MeOC}_{6} \mathrm{H}_{4}$ & $4.17 \pm 0.33$ & $3.63 \pm 0.23$ & $>20$ & $>25$ \\
\hline 110 & $4-\mathrm{BnOC}_{6} \mathrm{H}_{4}$ & $\mathrm{Ph}$ & $13.44 \pm 1.18$ & $>20$ & $>20$ & $>25$ \\
\hline 120 & 2-Thienyl & $4-\mathrm{BrC}_{6} \mathrm{H}_{4}$ & $11.73 \pm 1.39$ & $>20$ & $>20$ & $>25$ \\
\hline 121 & 2-Thienyl & $4-\mathrm{MeC}_{6} \mathrm{H}_{4}$ & $13.88 \pm 1.74$ & $>20$ & $>20$ & $>25$ \\
\hline Methotrexate $^{c}$ & & & $0.01 \pm 0.001$ & ND & $5.79 \pm 0.47$ & ND \\
\hline Nilotinib $^{c}$ & & & $0.04 \pm 0.001$ & $9.60 \pm 0.51$ & ND & ND \\
\hline
\end{tabular}

${ }^{a}$ Concentration $(\mu \mathrm{M})$ required to inhibit tumor cell growth by $50 \%$, values are mean of three independent experiments. ${ }^{b}$ Standard error of the mean. ${ }^{c}$ Positive controls, ND $=$ not determined.

The molecules aligned to the iso-surface of 3D-QSAR model on electrostatic potential grid and van der Waals grid are shown in Fig. 3. Red colour in the electrostatic grid (Fig. 3A) symbolizes that an increase in electron density in this region should increase the activity, while blue colour represents area where lower electron density is expected to be beneficial for the activity. Likewise, green contour in steric map (Fig. 3B) indicates a potential increase in the activity with sterically bulky groups in these regions, while yellow contour shows areas where an increase in the steric bulk would result in a lower activity. ${ }^{21}$

The 3D-QSAR map suggested that compounds bearing a high electron density and bulky group at $\mathrm{R}^{1}$ position would show higher activity. Despite the high residual error (0.69) observed for compound 101, this 3D-QSAR map validated its highest activity as the dimethylamino group at the $\mathrm{R}^{1}$ phenyl ring clearly met the above description, particularly on the electrostatic grid.
The good antiproliferative activity of compounds bearing a para-methoxy group at the $\mathrm{R}^{1}$ phenyl was also well aligned with the model. The positioning of the most active in the series compound $101\left(\mathrm{GI}_{50}=0.06 \mu \mathrm{M}\right)$ in the electrostatic and van der Waals grids is shown in Fig. 4.

\section{Conclusions}

We synthesized a library of 6, $N^{2}$-diaryl-1,3,5-triazine-2,4-diamines and evaluated their antiproliferative properties against three breast cancer cell lines. It was found that MDA-MB231 triple negative breast cancer cells were more sensitive to the prepared compounds than SKBR-3 and MCF-7 cells. The active compounds also demonstrated no inhibition on the growth of non-cancerous MCF-10A breast cells. The 3D-QSAR model constructed using the obtained data could be used for the further design of compoundstargeting triple negative breast cancer cells. 


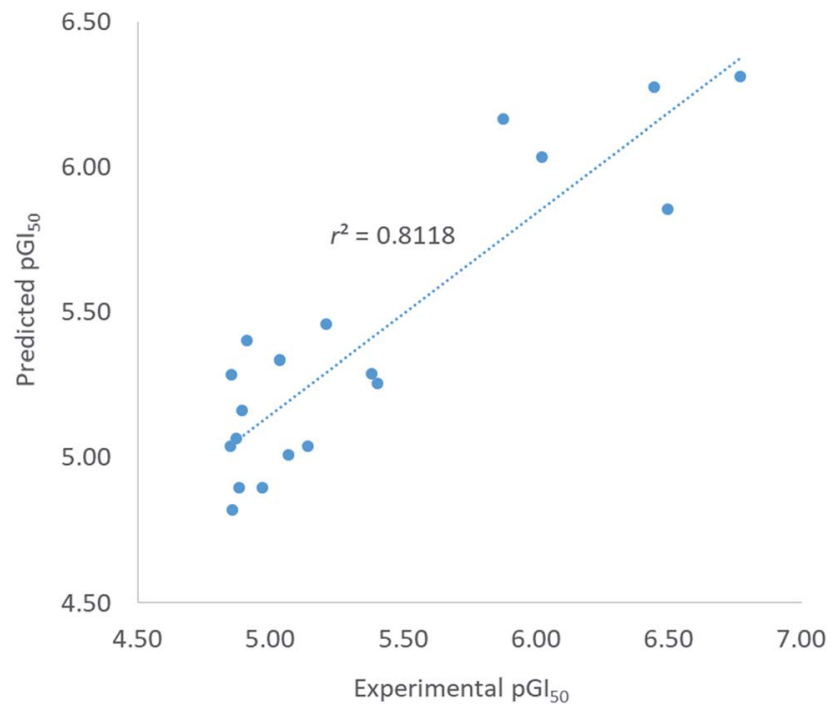

Fig. 2 Plot of experimental versus predicted $\left.p G\right|_{50}$ activity of training set.

Table 3 Experimental and predicted by 3D-QSAR model inhibitory activities of compounds ${ }^{a}$

\begin{tabular}{lllr}
\hline & $\begin{array}{l}\text { Experimental } \\
\text { Compound }\end{array}$ & $\begin{array}{l}\text { Predicted } \\
\text { pGI }_{50}\end{array}$ & Residual error \\
\hline $\mathbf{1 4}$ & 5.04 & 5.33 & -0.30 \\
$\mathbf{1 6}$ & 4.88 & 4.90 & -0.01 \\
$\mathbf{1 7}$ & 5.40 & 5.26 & 0.15 \\
$\mathbf{1 8}$ & 5.21 & 5.46 & -0.25 \\
$\mathbf{1 9}$ & 5.07 & 5.01 & 0.06 \\
$\mathbf{3 6}$ & 4.85 & 5.04 & -0.19 \\
$\mathbf{5 6}$ & 6.77 & 6.31 & 0.46 \\
$\mathbf{5 8}$ & 4.82 & 5.23 & -0.41 \\
$\mathbf{6 1}$ & 4.91 & 5.40 & -0.49 \\
$\mathbf{6 2}$ & 4.97 & 4.89 & 0.08 \\
$\mathbf{7 0}$ & 6.49 & 5.85 & 0.64 \\
$\mathbf{7 3}$ & 6.64 & 6.10 & 0.54 \\
$\mathbf{7 4}$ & 5.88 & 6.16 & -0.29 \\
$\mathbf{7 7}$ & 6.02 & 6.03 & -0.01 \\
$\underline{\mathbf{7 8}}$ & 4.88 & 5.78 & -0.90 \\
$\mathbf{7 1}$ & 4.85 & 5.29 & -0.43 \\
$\mathbf{9 5}$ & 4.89 & 5.16 & -0.27 \\
$\mathbf{9 9}$ & 4.94 & 4.28 & 0.66 \\
$\mathbf{1 0 0}$ & 6.44 & 6.27 & 0.17 \\
$\underline{\mathbf{1 0 1}}$ & 7.22 & 6.55 & 0.67 \\
$\mathbf{1 0 2}$ & 5.14 & 5.04 & 0.10 \\
$\mathbf{1 0 3}$ & 5.38 & 5.29 & 0.09 \\
$\mathbf{1 1 0}$ & 4.87 & 5.07 & -0.20 \\
$\underline{\mathbf{1 2 0}}$ & 4.93 & 4.46 & 0.47 \\
$\mathbf{1 2 1}$ & 4.86 & 4.82 & 0.04 \\
& & &
\end{tabular}

${ }^{a}$ Underlined compounds were randomly selected for test set.

\section{Experimental}

\section{General}

Melting points (uncorrected) were determined on a Stuart ${ }^{\mathrm{TM}}$ SMP40 automatic melting point apparatus. ${ }^{1} \mathrm{H}$ and ${ }^{13} \mathrm{C}$ NMR
(A)

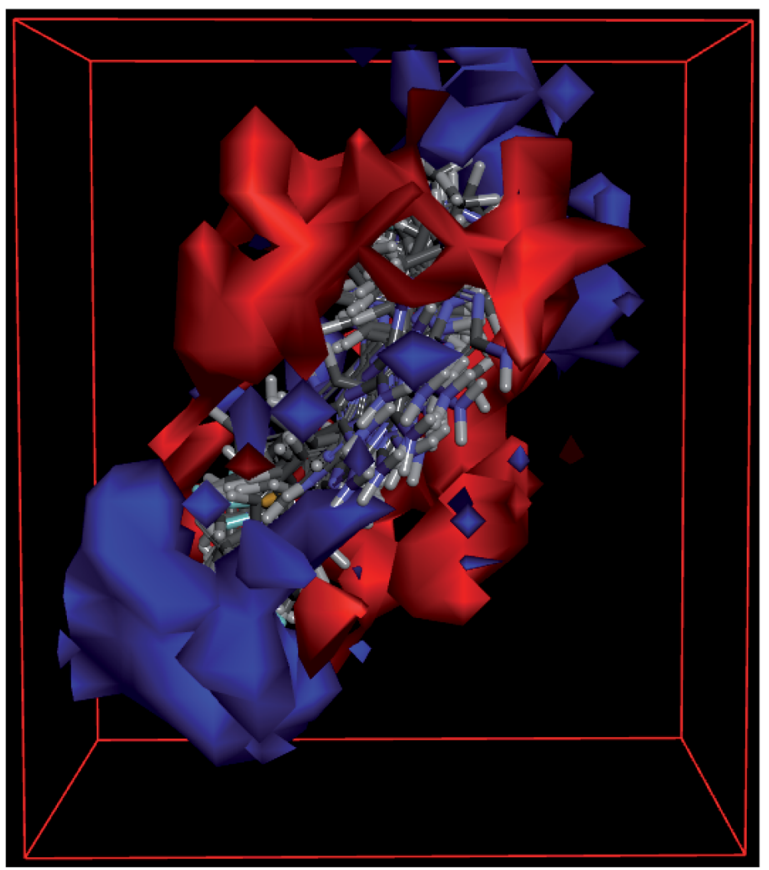

(B)

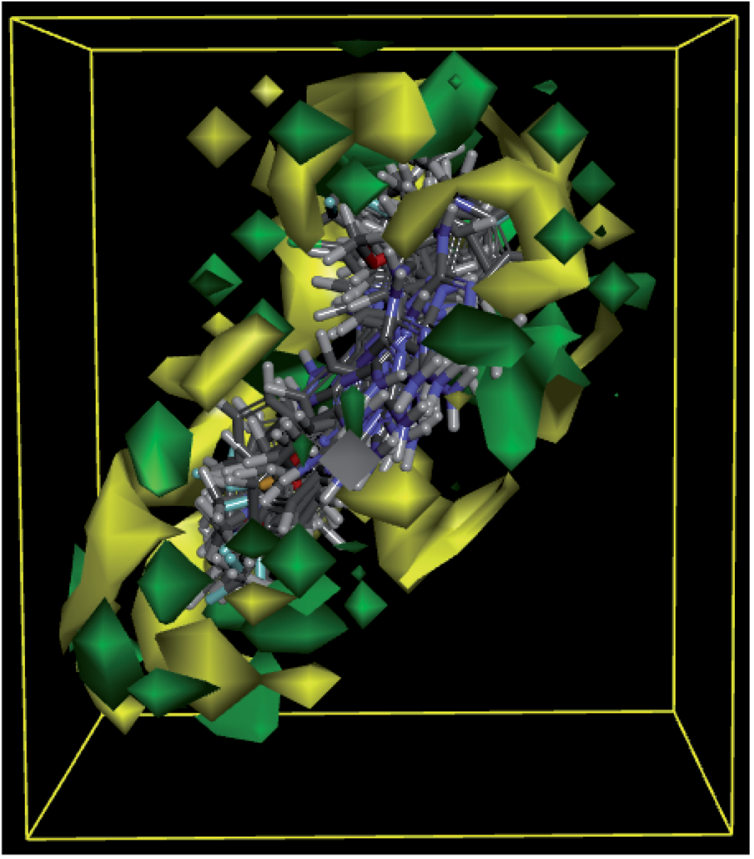

Fig. 3 3D-QSAR model coefficients on electrostatic grid (A) and van der Waals grid $(B)$

spectra were recorded on a Bruker Fourier NMR spectrometer (300 MHz) using DMSO- $d_{6}$ as a solvent and TMS as an internal reference. Microwave-assisted reactions were carried out in the closed vessel focused single mode using a Discover SP microwave synthesizer (CEM, USA) monitoring reaction temperature by the equipped IR sensor. The synthesis of compounds 1, 5-29, 31-33, 35-52, 54-56, 58, 60-64, 66-70, 72-83, 85-90, 92-110, 112-115, 117-121, 124-126 and their characterization were described earlier. ${ }^{\mathbf{1 6}}$ 
(A)

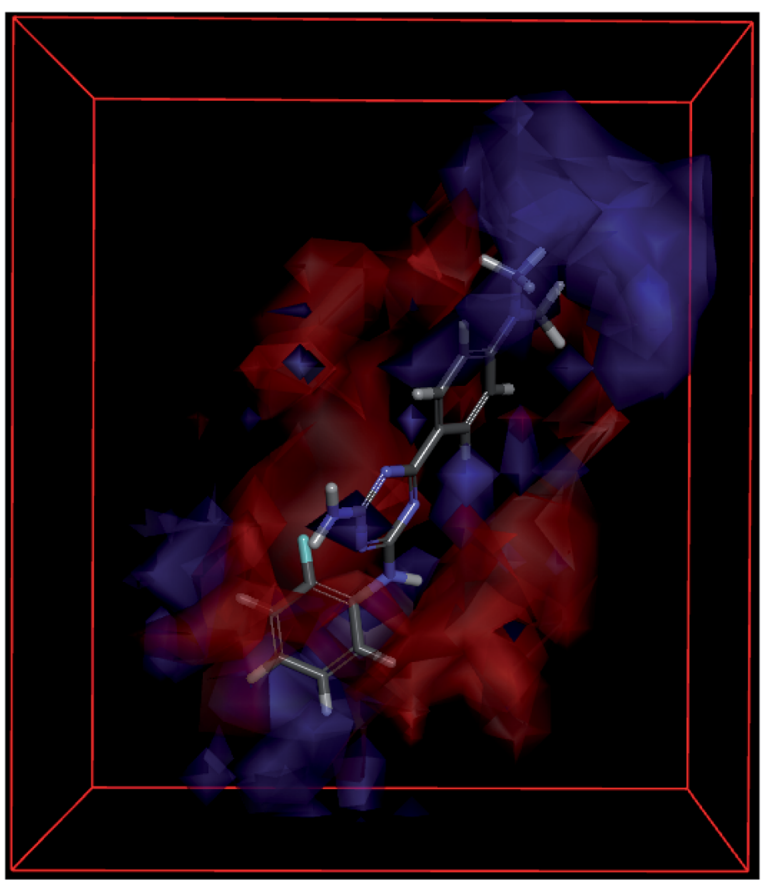

(B)

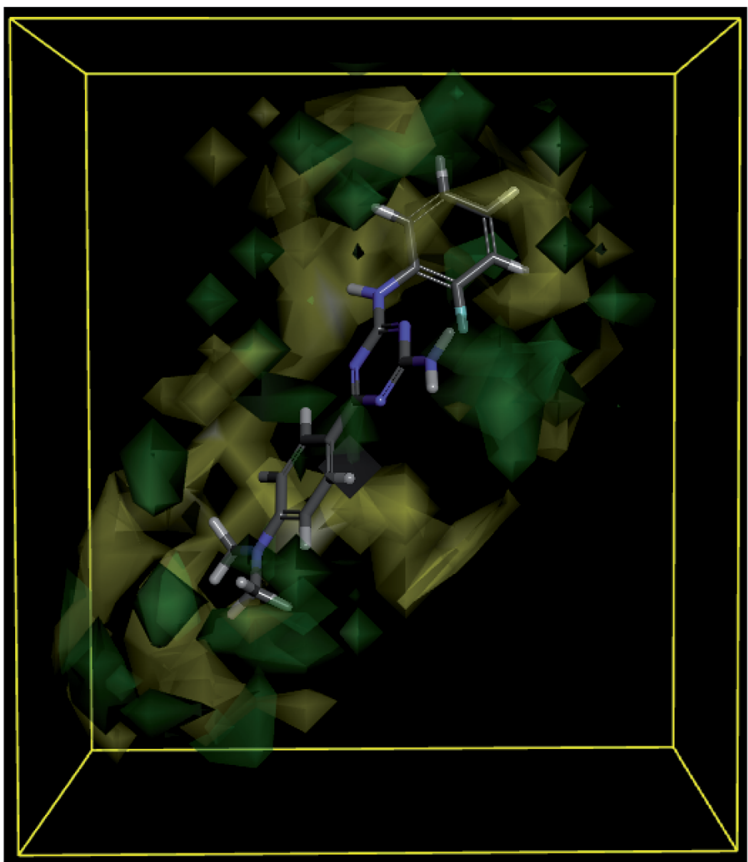

Fig. 4 3D-QSAR model coefficients of compound 101 on electrostatic grid (A) and van der Waals grid (B).

General method for the synthesis of $6, N^{2}$-diaryl-1,3,5-triazine2,4-diamines (1-126)

To a solution of cyanoguanidine $(0.21 \mathrm{~g}, 2.5 \mathrm{mmol})$, an aromatic aldehyde $(2.5 \mathrm{mmol})$ and an arylamine $(2.5 \mathrm{mmol})$ in EtOH (2 $\mathrm{mL})$ in a $10 \mathrm{~mL}$ seamless pressure vial, conc. $\mathrm{HCl}(0.21 \mathrm{~mL}, 2.5$ $\mathrm{mmol}$ ) was added. The reaction mixture was heated at $140{ }^{\circ} \mathrm{C}$ for $50 \mathrm{~min}$ by irradiation in the Discover SP (CEM) microwave reactor operating at maximal microwave power up to $150 \mathrm{~W}$.
Then, an aq. solution of $\mathrm{NaOH}(5 \mathrm{~N}, 1 \mathrm{~mL})$ was added to the reaction mixture and heating was continued for another $15 \mathrm{~min}$ at $140{ }^{\circ} \mathrm{C}$. After cooling, the precipitated product was filtered, washed with water and recrystallized from a suitable solvent.

\section{$N^{2}$-(2-Fluorophenyl)-6-phenyl-1,3,5-triazine-2,4-diamine (2)}

Yield $0.12 \mathrm{~g}, 30 \%$. Mp 156-158 ${ }^{\circ} \mathrm{C}$ (EtOH). ${ }^{1} \mathrm{H}$ NMR $(300 \mathrm{MHz}$, DMSO- $\left.d_{6}\right): \delta 7.08\left(2 \mathrm{H}\right.$, brs, $\left.\mathrm{NH}_{2}\right), 7.17-7.30\left(3 \mathrm{H}, \mathrm{m}, \mathrm{H}-3^{\prime \prime}, \mathrm{H}-4^{\prime \prime}\right.$ and $\left.\mathrm{H}-5^{\prime \prime}\right), 7.46-7.54\left(3 \mathrm{H}, \mathrm{m}, \mathrm{H}-3^{\prime}, \mathrm{H}-4^{\prime}\right.$ and $\left.\mathrm{H}-5^{\prime}\right), 7.75-7.81(1 \mathrm{H}$, $\left.\mathrm{m}, \mathrm{H}-6^{\prime \prime}\right), 8.28\left(2 \mathrm{H}, \mathrm{dd}, J=1.6 \mathrm{~Hz}, J=8.1 \mathrm{~Hz}, \mathrm{H}-2^{\prime}\right.$ and $\left.\mathrm{H}-6^{\prime}\right), 9.02$ $(1 \mathrm{H}, \mathrm{s}, \mathrm{NH}) ;{ }^{13} \mathrm{C}$ NMR (75 MHz, DMSO- $\left.d_{6}\right): \delta 115.5\left(\mathrm{~d},{ }^{2} J_{\mathrm{CF}}=\right.$ $\left.19.4 \mathrm{~Hz}, \mathrm{C}-3^{\prime \prime}\right), 124.0$ (d, $\left.{ }^{3} J_{\mathrm{CF}}=3.7 \mathrm{~Hz}, \mathrm{C}-6^{\prime \prime}\right), 125.5\left(\mathrm{~d},{ }^{3} J_{\mathrm{CF}}=\right.$ $\left.7.5 \mathrm{~Hz}, \mathrm{C}-4^{\prime \prime}\right), 126.6$ (d, $\left.{ }^{4} J_{\mathrm{CF}}=1.5 \mathrm{~Hz}, \mathrm{C}-5^{\prime \prime}\right), 126.7\left(\mathrm{~d},{ }^{2} J_{\mathrm{CF}}=\right.$ $\left.12.0 \mathrm{~Hz}, \mathrm{C}-1^{\prime \prime}\right), 127.7$ (C-3' and C-5'), $128.2\left(\mathrm{C}-2^{\prime}\right.$ and C-6 $\left.{ }^{\prime}\right), 131.3$ $\left(\mathrm{C}-4^{\prime}\right), 136.6\left(\mathrm{C}-1^{\prime}\right), 155.4\left(\mathrm{~d},{ }^{1} J_{\mathrm{CF}}=245.9 \mathrm{~Hz}, \mathrm{C}-2^{\prime \prime}\right), 165.2(\mathrm{C}-4)$, 167.3 (C-6), 170.2 (C-2). Anal. calcd for $\mathrm{C}_{15} \mathrm{H}_{12} \mathrm{FN}_{5}$ : C, 64.05; H, 4.30 ; N, 24.90. Found: C, 63.96; H, 4.41; N, 24.77.

\section{$N^{2}$-(4-Fluorophenyl)-6-phenyl-1,3,5-triazine-2,4-diamine (3)}

Yield $0.25 \mathrm{~g}, 37 \%$. Mp $172-174{ }^{\circ} \mathrm{C}$ (EtOH). ${ }^{1} \mathrm{H}$ NMR $(300 \mathrm{MHz}$, DMSO- $\left.d_{6}\right): \delta 7.13\left(2 \mathrm{H}\right.$, brs, $\left.\mathrm{NH}_{2}\right), 7.15\left(2 \mathrm{H}, \mathrm{dd},{ }^{3} J_{\mathrm{HF}}=8.8 \mathrm{~Hz}\right.$, ${ }^{3} J_{\mathrm{HH}}=9.2 \mathrm{~Hz}, \mathrm{H}-3^{\prime \prime}$ and $\left.\mathrm{H}-5^{\prime \prime}\right), 7.48-7.56\left(3 \mathrm{H}, \mathrm{m}, \mathrm{H}-3^{\prime}, \mathrm{H}-4^{\prime}\right.$ and $\left.\mathrm{H}-5^{\prime}\right), 7.85\left(2 \mathrm{H}, \mathrm{dd},{ }^{4} J_{\mathrm{HF}}=5.0 \mathrm{~Hz},{ }^{3} J_{\mathrm{HH}}=9.2 \mathrm{~Hz}, \mathrm{H}-2^{\prime \prime}\right.$ and $\left.\mathrm{H}-6^{\prime \prime}\right)$, $8.32\left(2 \mathrm{H}, \mathrm{dd}, J=1.7 \mathrm{~Hz}, J=8.1 \mathrm{~Hz}, \mathrm{H}-2^{\prime}\right.$ and $\left.\mathrm{H}^{\prime} 6^{\prime}\right), 9.57(1 \mathrm{H}, \mathrm{s}$, $\mathrm{NH}) ;{ }^{13} \mathrm{C}$ NMR (75 MHz, DMSO- $\left.d_{6}\right): \delta 114.9\left(\mathrm{~d},{ }^{2} J_{\mathrm{CF}}=22.0 \mathrm{~Hz}, \mathrm{C}-\right.$ $3^{\prime \prime}$ and $\left.\mathrm{C}-5^{\prime \prime}\right), 121.6\left(\mathrm{~d},{ }^{3} J_{\mathrm{CF}}=8.2 \mathrm{~Hz}, \mathrm{C}-2^{\prime \prime}\right.$ and C- $\left.6^{\prime \prime}\right), 127.7\left(\mathrm{C}-3^{\prime}\right.$ and $\left.\mathrm{C}-5^{\prime}\right), 128.2\left(\mathrm{C}-2^{\prime}\right.$ and $\left.\mathrm{C}-6^{\prime}\right), 131.3\left(\mathrm{C}-4^{\prime}\right), 136.2\left(\mathrm{~d},{ }^{4} J_{\mathrm{CF}}=\right.$ $\left.2.2 \mathrm{~Hz}, \mathrm{C}-1^{\prime \prime}\right), 136.7$ (C-1'), $157.4\left(\mathrm{~d},{ }^{1} J_{\mathrm{CF}}=238.6 \mathrm{~Hz}, \mathrm{C}-4^{\prime \prime}\right), 164.5$ (C-4), 167.1 (C-6), 170.2 (C-2). Anal. calcd for $\mathrm{C}_{15} \mathrm{H}_{12} \mathrm{FN}_{5}$ : C, 64.05; H, 4.30; N, 24.90. Found: C, 63.97; H, 4.38; N, 24.81.

\section{$N^{2}$-(2-Chlorophenyl)-6-phenyl-1,3,5-triazine-2,4-diamine (4)}

Yield $0.26 \mathrm{~g}, 35 \%$. Mp $82-84{ }^{\circ} \mathrm{C}\left(\mathrm{EtOH} / \mathrm{H}_{2} \mathrm{O}\right) .{ }^{1} \mathrm{H}$ NMR $(300 \mathrm{MHz}$, DMSO- $\left.d_{6}\right): \delta 7.10\left(2 \mathrm{H}\right.$, brs, $\left.\mathrm{NH}_{2}\right), 7.20(1 \mathrm{H}, \mathrm{ddd}, J=1.6 \mathrm{~Hz}, J=$ $\left.7.5 \mathrm{~Hz}, J=7.9 \mathrm{~Hz}, \mathrm{H}-4^{\prime \prime}\right), 7.37(1 \mathrm{H}, \mathrm{ddd}, J=1.5 \mathrm{~Hz}, J=7.5 \mathrm{~Hz}, J=$ $\left.8.0 \mathrm{~Hz}, \mathrm{H}-5^{\prime \prime}\right), 7.46-7.54\left(4 \mathrm{H}, \mathrm{m}, \mathrm{H}-3^{\prime}, \mathrm{H}-5^{\prime}, \mathrm{H}-4^{\prime}\right.$ and $\left.\mathrm{H}-3^{\prime \prime}\right), 7.84$ $\left(1 \mathrm{H}, \mathrm{dd}, J=1.6 \mathrm{~Hz}, J=8.0 \mathrm{~Hz}, \mathrm{H}-6^{\prime \prime}\right), 8.26(2 \mathrm{H}, \mathrm{dd}, J=1.6 \mathrm{~Hz}, J=$ $6.7 \mathrm{~Hz}, \mathrm{H}-2^{\prime}$ and $\left.\mathrm{H}^{-6}\right), 8.75(1 \mathrm{H}, \mathrm{s}, \mathrm{NH}) ;{ }^{13} \mathrm{C} \mathrm{NMR}(75 \mathrm{MHz}$, DMSO- $\left.d_{6}\right): \delta 125.9\left(\mathrm{C}-6^{\prime \prime}\right), 127.1\left(\mathrm{C}-4^{\prime \prime}\right), 127.3\left(\mathrm{C}-2^{\prime \prime}\right), 127.7\left(\mathrm{C}-3^{\prime}\right.$ and $\left.\mathrm{C}-5^{\prime}\right), 128.0\left(\mathrm{C}-5^{\prime \prime}\right), 128.2\left(\mathrm{C}-2^{\prime}\right.$ and $\left.\mathrm{C}-6^{\prime}\right), 129.3\left(\mathrm{C}-3^{\prime \prime}\right), 131.3$ $\left(\mathrm{C}-4^{\prime}\right), 135.7\left(\mathrm{C}-1^{\prime \prime}\right), 136.5\left(\mathrm{C}-1^{\prime}\right), 165.1$ (C-4), 167.2 (C-6), 170.2 (C2). Anal. calcd for $\mathrm{C}_{15} \mathrm{H}_{12} \mathrm{ClN}_{5}: \mathrm{C}, 60.51 ; \mathrm{H}, 4.06 ; \mathrm{N}, 23.52$. Found: C, 60.39; H, 4.15; N, 23.44.

\section{6-(4-Fluorophenyl)- $N^{2}$-(4-methoxyphenyl)-1,3,5-triazine-2,4- diamine (30)}

Yield 0.20 g, 30\%. Mp 158-160 ${ }^{\circ} \mathrm{C}(\mathrm{MeCN}) .{ }^{1} \mathrm{H}$ NMR $(300 \mathrm{MHz}$, DMSO- $\left.d_{6}\right): \delta 3.75\left(3 \mathrm{H}, \mathrm{s}, \mathrm{OCH}_{3}\right), 6.91\left(2 \mathrm{H}, \mathrm{d}, J=9.0 \mathrm{~Hz}, \mathrm{H}-3^{\prime \prime}\right.$ and $\left.\mathrm{H}-5^{\prime \prime}\right), 7.06\left(2 \mathrm{H}, \mathrm{brs}, \mathrm{NH}_{2}\right), 7.33\left(2 \mathrm{H}, \mathrm{dd},{ }^{3} J_{\mathrm{HF}}=9.0 \mathrm{~Hz},{ }^{3} J_{\mathrm{HH}}=\right.$ $8.8 \mathrm{~Hz}, \mathrm{H}-3^{\prime}$ and $\left.\mathrm{H}-5^{\prime}\right), 7.70\left(2 \mathrm{H}, \mathrm{d}, J=8.9 \mathrm{~Hz}, \mathrm{H}-2^{\prime \prime}\right.$ and $\left.\mathrm{H}-6^{\prime \prime}\right)$, $8.36\left(2 \mathrm{H}, \mathrm{dd},{ }^{4} J_{\mathrm{HF}}=5.8 \mathrm{~Hz},{ }^{3} J_{\mathrm{HH}}=8.8 \mathrm{~Hz}, \mathrm{H}-2^{\prime}\right.$ and $\left.\mathrm{H}-6^{\prime}\right), 9.37$ $(1 \mathrm{H}, \mathrm{s}, \mathrm{NH}) ;{ }^{13} \mathrm{C}$ NMR (75 MHz, DMSO- $\left.d_{6}\right): \delta 55.1\left(\mathrm{OCH}_{3}\right), 113.6$ $\left(\mathrm{C}-3^{\prime \prime}\right.$ and C-5"), 115.1 (d, ${ }^{2} J_{\mathrm{CF}}=21.7 \mathrm{~Hz}, \mathrm{C}-3^{\prime}$ and C-5'), $121.8(\mathrm{C}-$ $2^{\prime \prime}$ and C- $\left.6^{\prime \prime}\right), 130.1\left(\mathrm{~d},{ }^{3} J_{\mathrm{CF}}=8.9 \mathrm{~Hz}, \mathrm{C}-2^{\prime}\right.$ and $\left.\mathrm{C}-6^{\prime}\right), 132.8\left(\mathrm{C}-1^{\prime \prime}\right)$, $133.3\left(\mathrm{~d},{ }^{4} J_{\mathrm{CF}}=2.7 \mathrm{~Hz}, \mathrm{C}-1^{\prime}\right), 154.7\left(\mathrm{C}-4^{\prime \prime}\right), 164.1\left(\mathrm{~d},{ }^{1} J_{\mathrm{CF}}=\right.$ 
$248.3 \mathrm{~Hz}, \mathrm{C}-4^{\prime}$ ), 164.4 (C-4), 167.1 (C-6), 169.1 (C-2). Anal. calcd for $\mathrm{C}_{16} \mathrm{H}_{14} \mathrm{FN}_{5} \mathrm{O}: \mathrm{C}, 61.73 ; \mathrm{H}, 4.53 ; \mathrm{N}, 22.50$. Found: $\mathrm{C}, 61.60 ; \mathrm{H}$, $4.65 ; \mathrm{N}, 22.34$.

\section{6-(4-Chlorophenyl)- $N^{2}$-phenyl-1,3,5-triazine-2,4-diamine (34)}

Yield $0.25 \mathrm{~g}, 33 \%$. Mp 154-156 ${ }^{\circ} \mathrm{C}$ (EtOH). ${ }^{1} \mathrm{H}$ NMR $(300 \mathrm{MHz}$, DMSO- $\left.d_{6}\right): \delta 7.01\left(1 \mathrm{H}, \mathrm{t}, J=7.9 \mathrm{~Hz}, \mathrm{H}-4^{\prime \prime}\right), 7.19\left(2 \mathrm{H}, \mathrm{brs}, \mathrm{NH}_{2}\right)$, $7.32\left(2 \mathrm{H}, \mathrm{t}, J=7.9 \mathrm{~Hz}, \mathrm{H}-3^{\prime \prime}\right.$ and $\left.\mathrm{H}-5^{\prime \prime}\right), 7.60(2 \mathrm{H}, \mathrm{d}, J=8.6 \mathrm{~Hz}, \mathrm{H}-$ $3^{\prime}$ and $\left.\mathrm{H}-5^{\prime}\right), 7.85\left(2 \mathrm{H}, \mathrm{d}, J=7.9 \mathrm{~Hz}, \mathrm{H}-2^{\prime \prime}\right.$ and $\left.\mathrm{H}-6^{\prime \prime}\right), 8.33(2 \mathrm{H}, \mathrm{d}, J$ $=8.7 \mathrm{~Hz}, \mathrm{H}-2^{\prime}$ and $\left.\mathrm{H}^{\prime} 6^{\prime}\right), 9.58(1 \mathrm{H}, \mathrm{s}, \mathrm{NH}) ;{ }^{13} \mathrm{C}$ NMR $(75 \mathrm{MHz}$, DMSO- $\left.d_{6}\right): \delta 120.0\left(\mathrm{C}-2^{\prime \prime}\right.$ and C- $\left.6^{\prime \prime}\right), 122.0\left(\mathrm{C}-1^{\prime \prime}\right), 128.4\left(\mathrm{C}-3^{\prime}, \mathrm{C}-5^{\prime}\right.$, C-3" and C-5"), 129.5 (C-2' and C-6'), $135.6\left(\mathrm{C}-1^{\prime}\right), 136.1\left(\mathrm{C}-4^{\prime}\right)$, 139.8 (C-4"), 164.5 (C-4), 167.1 (C-6), 169.2 (C-2). Anal. calcd for $\mathrm{C}_{15} \mathrm{H}_{12} \mathrm{ClN}_{5}$ : C, 60.51; H, 4.06; N, 23.52. Found: C, 60.46; H, $4.20 ; \mathrm{N}, 23.36$.

\section{$N^{2}$-(4-Fluorophenyl)-6-(3-methylphenyl)-1,3,5-triazine-2,4- diamine (53)}

Yield 0.25 g, 35\%. Mp $138-139{ }^{\circ} \mathrm{C}\left(\mathrm{EtOH} / \mathrm{H}_{2} \mathrm{O}\right) .{ }^{1} \mathrm{H}$ NMR $(300$ MHz, DMSO- $\left.d_{6}\right): \delta 2.40\left(3 \mathrm{H}, \mathrm{s}, \mathrm{CH}_{3}\right), 7.13\left(2 \mathrm{H}, \mathrm{brs}, \mathrm{NH}_{2}\right), 7.15$ $\left(2 \mathrm{H}, \mathrm{dd},{ }^{3} J_{\mathrm{HF}}=8.9 \mathrm{~Hz},{ }^{3} J_{\mathrm{HH}}=8.9 \mathrm{~Hz}, \mathrm{H}-3^{\prime \prime}\right.$ and $\left.\mathrm{H}-5^{\prime \prime}\right), 7.37-7.42$ $\left(2 \mathrm{H}, \mathrm{m}, \mathrm{H}-4^{\prime}\right.$ and $\left.\mathrm{H}-5^{\prime}\right), 7.85\left(2 \mathrm{H}, \mathrm{dd},{ }^{4} J_{\mathrm{HF}}=5.0 \mathrm{~Hz},{ }^{3} J_{\mathrm{HH}}=\right.$ $9.1 \mathrm{~Hz}, \mathrm{H}-2^{\prime \prime}$ and $\left.\mathrm{H}-6^{\prime \prime}\right), 8.10-8.16\left(2 \mathrm{H}, \mathrm{m}, \mathrm{H}-2^{\prime}\right.$ and $\left.\mathrm{H}-6^{\prime}\right), 9.56$ $(1 \mathrm{H}, \mathrm{s}, \mathrm{NH}) ;{ }^{13} \mathrm{C}$ NMR $\left(75 \mathrm{MHz}, \mathrm{DMSO}-d_{6}\right): \delta 21.0\left(\mathrm{CH}_{3}\right), 114.8(\mathrm{~d}$, ${ }^{2} J_{\mathrm{CF}}=21.6 \mathrm{~Hz}, \mathrm{C}-2^{\prime \prime}$ and C- $\left.6^{\prime \prime}\right), 121.5\left(\mathrm{~d},{ }^{3} J_{\mathrm{CF}}=7.5 \mathrm{~Hz}, \mathrm{C}-3^{\prime \prime}\right.$ and C-5 $\left.{ }^{\prime \prime}\right), 124.9\left(\mathrm{C}^{\prime} 2^{\prime}\right), 128.1\left(\mathrm{C}-6^{\prime}\right), 128.3\left(\mathrm{C}-5^{\prime}\right), 131.9\left(\mathrm{C}-4^{\prime}\right), 136.3$ (d, $\left.{ }^{4} J_{\mathrm{CF}}=3.0 \mathrm{~Hz}, \mathrm{C}-1^{\prime \prime}\right), 136.7\left(\mathrm{C}-3^{\prime}\right), 137.3\left(\mathrm{C}-1^{\prime}\right), 157.4\left(\mathrm{~d},{ }^{1} J_{\mathrm{CF}}=\right.$ $238.4 \mathrm{~Hz}, \mathrm{C}-4^{\prime \prime}$ ), 164.4 (C-2), 167.1 (C-4), 170.2 (C-6). Anal. calcd for $\mathrm{C}_{16} \mathrm{H}_{14} \mathrm{FN}_{5}$ : C, 65.07; H, 4.78; N, 23.71. Found: C, 64.95; H, $4.91 ; \mathrm{N}, 23.58$.

\section{$N^{2}$-(4-Methoxyphenyl)-6-(3-methylphenyl)-1,3,5-triazine-2,4- diamine (57)}

Yield $0.22 \mathrm{~g}, 30 \%$. Mp 150-152 ${ }^{\circ} \mathrm{C}\left(\mathrm{EtOH} / \mathrm{H}_{2} \mathrm{O}\right) .{ }^{1} \mathrm{H}$ NMR $(300$ MHz, DMSO- $\left.d_{6}\right): \delta 2.39\left(3 \mathrm{H}, \mathrm{s}, \mathrm{CH}_{3}\right), 3.74\left(\mathrm{OCH}_{3}\right), 6.89(2 \mathrm{H}, \mathrm{d}, J$ $=9.0 \mathrm{~Hz}, \mathrm{H}-3^{\prime \prime}$ and $\left.\mathrm{H}-5^{\prime \prime}\right), 7.02\left(2 \mathrm{H}\right.$, brs, $\left.\mathrm{NH}_{2}\right), 7.34-7.41(2 \mathrm{H}, \mathrm{m}$, $\mathrm{H}-4^{\prime}$ and $\left.\mathrm{H}-5^{\prime}\right), 7.71\left(2 \mathrm{H}, \mathrm{d}, J=9.1 \mathrm{~Hz}, \mathrm{H}-2^{\prime \prime}\right.$ and $\left.\mathrm{H}-6^{\prime \prime}\right), 8.09-8.15$ $\left(2 \mathrm{H}, \mathrm{m}, \mathrm{H}-2^{\prime}\right.$ and $\left.\mathrm{H}-6{ }^{\prime}\right), 9.34(1 \mathrm{H}, \mathrm{s}, \mathrm{NH}) ;{ }^{13} \mathrm{C} \mathrm{NMR}(75 \mathrm{MHz}$, DMSO- $\left.d_{6}\right): \delta 21.0\left(\mathrm{CH}_{3}\right), 55.1\left(\mathrm{OCH}_{3}\right), 113.6\left(\mathrm{C}-3^{\prime \prime}\right.$ and $\left.\mathrm{C}-5^{\prime \prime}\right)$, $121.6\left(\mathrm{C}-2^{\prime \prime}\right.$ and $\left.\mathrm{C}-6^{\prime \prime}\right), 124.9\left(\mathrm{C}-2^{\prime}\right), 128.1\left(\mathrm{C}-6^{\prime}\right), 128.3\left(\mathrm{C}-5^{\prime}\right)$, $131.8\left(\mathrm{C}-1^{\prime \prime}\right), 132.9\left(\mathrm{C}-4^{\prime}\right), 136.8\left(\mathrm{C}-3^{\prime}\right), 137.2\left(\mathrm{C}-1^{\prime}\right), 154.5\left(\mathrm{C}-4^{\prime \prime}\right)$, 164.4 (C-2), 167.1 (C-4), 170.1 (C-6). Anal. calcd for $\mathrm{C}_{17} \mathrm{H}_{17} \mathrm{~N}_{5} \mathrm{O}$ : C, 66.43; H, 5.58; N, 22.79. Found: C, 66.34; H, 5.70; N, 22.64.

\section{$N^{2}$-(4-Isopropylphenyl)-6-(3-methylphenyl)-1,3,5-triazine-2,4-} diamine (59)

Yield $0.36 \mathrm{~g}, 45 \%$. Mp $134-136{ }^{\circ} \mathrm{C}\left(\mathrm{EtOH} / \mathrm{H}_{2} \mathrm{O}\right) .{ }^{1} \mathrm{H}$ NMR $(300$ MHz, DMSO- $\left.d_{6}\right): \delta 1.20\left(6 \mathrm{H}, \mathrm{d}, J=6.9 \mathrm{~Hz},\left(\mathrm{CH}_{3}\right)_{2}\right), 2.40(3 \mathrm{H}, \mathrm{s}$, $\left.\mathrm{CH}_{3}\right), 2.85(1 \mathrm{H}, \mathrm{m}, J=7.0 \mathrm{~Hz}, \mathrm{CH}), 7.08\left(2 \mathrm{H}, \mathrm{brs}, \mathrm{NH}_{2}\right), 7.17(2 \mathrm{H}$, $\mathrm{d}, J=8.5 \mathrm{~Hz}, \mathrm{H}-3^{\prime \prime}$ and $\left.\mathrm{H}-5^{\prime \prime}\right), 7.34-7.42\left(2 \mathrm{H}, \mathrm{m}, \mathrm{H}-4^{\prime}\right.$ and $\left.\mathrm{H}-5^{\prime}\right)$, $7.75\left(2 \mathrm{H}, \mathrm{d}, J=8.6 \mathrm{~Hz}, \mathrm{H}-2^{\prime \prime}\right.$ and $\left.\mathrm{H}-6^{\prime \prime}\right), 8.12-8.18\left(2 \mathrm{H}, \mathrm{m}, \mathrm{H}-2^{\prime}\right.$ and $\left.\mathrm{H}-6^{\prime}\right), 9.44(1 \mathrm{H}, \mathrm{s}, \mathrm{NH}) ;{ }^{13} \mathrm{C} \mathrm{NMR}$ (75 MHz, DMSO- $\left.d_{6}\right): \delta 21.0$ $\left(\mathrm{CH}_{3}\right), 24.0\left(\left(\mathrm{CH}_{3}\right)_{2}\right), 32.8(\mathrm{CH}), 120.1\left(\mathrm{C}-2^{\prime \prime}\right.$ and C-6" $), 125.0(\mathrm{C}-$ $\left.2^{\prime}\right), 126.0\left(\mathrm{C}-3^{\prime \prime}\right.$ and $\left.\mathrm{C}-5^{\prime \prime}\right), 128.1\left(\mathrm{C}-6^{\prime}\right), 128.3\left(\mathrm{C}-5^{\prime}\right), 131.9\left(\mathrm{C}-4^{\prime}\right)$, $136.8\left(\mathrm{C}-3^{\prime}\right), 137.2\left(\mathrm{C}-1^{\prime}\right), 137.6\left(\mathrm{C}-1^{\prime \prime}\right), 142.0\left(\mathrm{C}-4^{\prime \prime}\right), 164.5(\mathrm{C}-2)$,
167.1 (C-4), 170.2 (C-6). Anal. calcd for $\mathrm{C}_{19} \mathrm{H}_{21} \mathrm{~N}_{5}$ : C, 71.45; $\mathrm{H}$, 6.63; N, 21.93. Found: C, 71.38; H, 6.69; N, 21.85.

\section{$N^{2}$-(4-Methoxyphenyl)-6-(4-methylphenyl)-1,3,5-triazine-2,4- diamine (65)}

Yield $0.45 \mathrm{~g}, 60 \%$. Mp 168-170 ${ }^{\circ} \mathrm{C}$ (EtOH). ${ }^{1} \mathrm{H}$ NMR $(300 \mathrm{MHz}$, DMSO- $\left.d_{6}\right): \delta 2.38\left(3 \mathrm{H}, \mathrm{s}, \mathrm{CH}_{3}\right), 3.74\left(3 \mathrm{H}, \mathrm{s}, \mathrm{OCH}_{3}\right), 6.90(2 \mathrm{H}, \mathrm{d}, J$ $=9.0 \mathrm{~Hz}, \mathrm{H}-3^{\prime \prime}$ and $\left.\mathrm{H}-5^{\prime \prime}\right), 7.00\left(2 \mathrm{H}\right.$, brs, $\left.\mathrm{NH}_{2}\right), 7.30(2 \mathrm{H}, \mathrm{d}, J=$ $8.2 \mathrm{~Hz}, \mathrm{H}-3^{\prime}$ and $\left.\mathrm{H}-5^{\prime}\right), 7.71\left(2 \mathrm{H}, \mathrm{d}, J=9.0 \mathrm{~Hz}, \mathrm{H}-2^{\prime \prime}\right.$ and $\left.\mathrm{H}-6^{\prime \prime}\right)$, $8.21\left(2 \mathrm{H}, \mathrm{d}, J=8.1 \mathrm{~Hz}, \mathrm{H}-2^{\prime}\right.$ and $\left.\mathrm{H}-6^{\prime}\right), 9.32(1 \mathrm{H}, \mathrm{s}, \mathrm{NH}) ;{ }^{13} \mathrm{C} \mathrm{NMR}$ (75 MHz, DMSO- $\left.d_{6}\right): \delta 21.0\left(\mathrm{CH}_{3}\right), 55.1\left(\mathrm{OCH}_{3}\right), 113.6\left(\mathrm{C}-3^{\prime \prime}\right.$ and C-5 $\left.{ }^{\prime \prime}\right), 121.6\left(\mathrm{C}-2^{\prime \prime}\right.$ and C-6 $\left.6^{\prime \prime}\right), 127.7\left(\mathrm{C}-3^{\prime}\right.$ and C-5 $), 128.8\left(\mathrm{C}-2^{\prime}\right.$ and C-6'), $132.9\left(\mathrm{C}-1^{\prime \prime}\right), 134.1\left(\mathrm{C}-1^{\prime}\right), 141.1\left(\mathrm{C}-4^{\prime}\right), 154.5\left(\mathrm{C}-4^{\prime \prime}\right), 164.5$ (C-4), 167.1 (C-6), 170.0 (C-2). Anal. calcd for $\mathrm{C}_{17} \mathrm{H}_{17} \mathrm{~N}_{5} \mathrm{O}: \mathrm{C}$, 66.43; H, 5.58; N, 22.79. Found: C, 66.34; H, 5.66; N, 22.70.

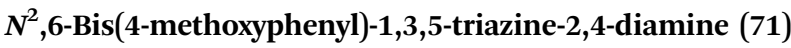

Yield $0.30 \mathrm{~g}, 38 \%$. Mp $163-165{ }^{\circ} \mathrm{C}(\mathrm{MeCN}) .{ }^{1} \mathrm{H}$ NMR $(300 \mathrm{MHz}$, DMSO- $\left.d_{6}\right): \delta 3.74\left(3 \mathrm{H}, \mathrm{s}, \mathrm{OCH}_{3}\right), 3.84\left(3 \mathrm{H}, \mathrm{s}, \mathrm{OCH}_{3}\right), 6.90(2 \mathrm{H}, \mathrm{d}, J$ $=9.0 \mathrm{~Hz}, \mathrm{H}-3^{\prime \prime}$ and $\left.\mathrm{H}-5^{\prime \prime}\right), 6.94\left(2 \mathrm{H}\right.$, brs, $\left.\mathrm{NH}_{2}\right), 7.05(2 \mathrm{H}, \mathrm{d}, J=$ $8.9 \mathrm{~Hz}, \mathrm{H}-3^{\prime}$ and $\left.\mathrm{H}-5^{\prime}\right), 7.71\left(2 \mathrm{H}, \mathrm{d}, J=9.0 \mathrm{~Hz}, \mathrm{H}-2^{\prime \prime}\right.$ and $\left.\mathrm{H}-6^{\prime \prime}\right)$, $8.28\left(2 \mathrm{H}, \mathrm{d}, J=8.9 \mathrm{~Hz}, \mathrm{H}-2^{\prime}\right.$ and $\left.\mathrm{H}-6^{\prime}\right), 9.28(1 \mathrm{H}, \mathrm{s}, \mathrm{NH}) ;{ }^{13} \mathrm{C} \mathrm{NMR}$ $\left(75 \mathrm{MHz}, \mathrm{DMSO}-d_{6}\right): \delta 55.1\left(\mathrm{OCH}_{3}\right), 55.2\left(\mathrm{OCH}_{3}\right), 113.5\left(\mathrm{C}-3^{\prime \prime}\right.$ and C-5 $\left.{ }^{\prime \prime}\right), 113.6$ (C-3' and C-5'), 121.6 (C-2" and C-6" $\left.{ }^{\prime \prime}\right), 129.1\left(\mathrm{C}-1^{\prime}\right)$, 129.5 (C-2' and C-6'), $133.0\left(\mathrm{C}-1^{\prime \prime}\right), 154.5\left(\mathrm{C}-4^{\prime}\right), 161.8\left(\mathrm{C}-4^{\prime \prime}\right)$, 164.4 (C-4), 167.0 (C-6), 169.6 (C-2). Anal. calcd for $\mathrm{C}_{17} \mathrm{H}_{17} \mathrm{~N}_{5} \mathrm{O}_{2}$ : C, 63.15; H, 5.30; N, 21.66. Found: C, 63.02; H, 5.41; N, 21.57.

\section{$N^{2}$-(4-Fluorophenyl)-6-(4-(trifluoromethyl)phenyl)-1,3,5- triazine-2,4-diamine (84)}

Yield $0.21 \mathrm{~g}, 28 \%$. Mp 150-152 ${ }^{\circ} \mathrm{C}$ (EtOH). ${ }^{1} \mathrm{H}$ NMR $(300 \mathrm{MHz}$, DMSO- $\left.d_{6}\right): \delta 7.16\left(2 \mathrm{H}, \mathrm{dd},{ }^{3} J_{\mathrm{HF}}=8.9 \mathrm{~Hz},{ }^{3} \mathrm{~J}_{\mathrm{HH}}=8.9 \mathrm{~Hz}, \mathrm{H}-3^{\prime \prime}\right.$ and $\left.\mathrm{H}-5^{\prime \prime}\right), 7.29\left(2 \mathrm{H}\right.$, brs, $\left.\mathrm{NH}_{2}\right), 7.85\left(2 \mathrm{H}, \mathrm{dd},{ }^{4} J_{\mathrm{HF}}=5.1 \mathrm{~Hz},{ }^{3} J_{\mathrm{HH}}=\right.$ $9.1 \mathrm{~Hz}, \mathrm{H}-2^{\prime \prime}$ and $\left.\mathrm{H}-6^{\prime \prime}\right), 7.90\left(2 \mathrm{H}, \mathrm{d},{ }^{3} J=8.6 \mathrm{~Hz}, \mathrm{H}-3^{\prime}\right.$ and $\left.\mathrm{H}-5^{\prime}\right)$, $8.50\left(2 \mathrm{H}, \mathrm{d}, J=8.6 \mathrm{~Hz}, \mathrm{H}-2^{\prime}\right.$ and $\left.\mathrm{H}-6^{\prime}\right), 9.70(1 \mathrm{H}, \mathrm{s}, \mathrm{NH}) ;{ }^{13} \mathrm{C} \mathrm{NMR}$ (75 MHz, DMSO- $d_{6}$ ): $\delta 114.9\left(\mathrm{~d},{ }^{2} J_{\mathrm{CF}}=22.5 \mathrm{~Hz}, \mathrm{C}-3^{\prime \prime}\right.$ and C-5 ${ }^{\prime \prime}$ ), $121.8\left(\mathrm{~d},{ }^{3} J_{\mathrm{CF}}=7.5 \mathrm{~Hz}, \mathrm{C}-2^{\prime \prime}\right.$ and C-6 $\left.{ }^{\prime \prime}\right), 124.1\left(\mathrm{q},{ }^{1} J_{\mathrm{CF}}=271.5 \mathrm{~Hz}\right.$, $\left.\mathrm{CF}_{3}\right), 125.3\left(\mathrm{q},{ }^{3} J_{\mathrm{CF}}=3.7 \mathrm{~Hz}, \mathrm{C}-3^{\prime}\right.$ and C-5 $\left.{ }^{\prime}\right), 128.4\left(\mathrm{C}-1^{\prime}\right), 131.1$ (q, $\left.{ }^{2} J_{\mathrm{CF}}=31.6 \mathrm{~Hz}, \mathrm{C}-4^{\prime}\right), 136.1\left(\mathrm{~d},{ }^{4} J_{\mathrm{CF}}=2.2 \mathrm{~Hz}, \mathrm{C}-1^{\prime \prime}\right), 140.6\left(\mathrm{q},{ }^{4} J_{\mathrm{CF}}\right.$ $=1.5 \mathrm{~Hz}, \mathrm{C}-2^{\prime}$ and C-6 $\left.{ }^{\prime}\right), 157.6\left(\mathrm{~d},{ }^{1} J_{\mathrm{CF}}=238.8 \mathrm{~Hz}, \mathrm{C}-4^{\prime \prime}\right), 164.5$ (C-4), 167.1 (C-6), 169.0 (C-2). Anal. calcd for $\mathrm{C}_{16} \mathrm{H}_{11} \mathrm{~F}_{4} \mathrm{~N}_{5}$ : C, 55.02; H, 3.17; N, 20.05. Found: C, 54.88; H, 3.26; N, 19.90.

\section{$N^{2}$-(4-Fluorophenyl)-6-(4-(trifluoromethoxy)phenyl)-1,3,5-} triazine-2,4-diamine (91)

Yield $0.32 \mathrm{~g}, 58 \%$. Mp $139-140{ }^{\circ} \mathrm{C}(\mathrm{EtOH}) .{ }^{1} \mathrm{H}$ NMR $(300 \mathrm{MHz}$, DMSO- $\left.d_{6}\right): \delta 7.16\left(2 \mathrm{H}, \mathrm{dd},{ }^{3} J_{\mathrm{HF}}=8.9 \mathrm{~Hz},{ }^{3} J_{\mathrm{HH}}=8.9 \mathrm{~Hz}, \mathrm{H}-3^{\prime \prime}\right.$ and $\left.\mathrm{H}-5^{\prime \prime}\right), 7.22\left(2 \mathrm{H}, \mathrm{brs}, \mathrm{NH}_{2}\right), 7.51\left(2 \mathrm{H}, \mathrm{d}, J=8.0 \mathrm{~Hz}, \mathrm{H}-3^{\prime}\right.$ and $\left.\mathrm{H}-5^{\prime}\right)$, $7.85\left(2 \mathrm{H}, \mathrm{dd},{ }^{4} J_{\mathrm{HF}}=5.0 \mathrm{~Hz},{ }^{3} J_{\mathrm{HH}}=9.0 \mathrm{~Hz}, \mathrm{H}-2^{\prime \prime}\right.$ and $\left.\mathrm{H}-6^{\prime \prime}\right), 8.42$ $\left(2 \mathrm{H}, \mathrm{d}, J=8.9 \mathrm{~Hz}, \mathrm{H}-2^{\prime}\right.$ and $\left.\mathrm{H}-6^{\prime}\right), 9.64(1 \mathrm{H}, \mathrm{s}, \mathrm{NH}) ;{ }^{13} \mathrm{C} \mathrm{NMR}(75$ MHz, DMSO- $\left.d_{6}\right): \delta 114.9\left(\mathrm{~d},{ }^{2} J_{\mathrm{CF}}=22.1 \mathrm{~Hz}, \mathrm{C}-3^{\prime \prime}\right.$ and C- $\left.5^{\prime \prime}\right), 119.4$ $\left(\mathrm{q},{ }^{1} J_{\mathrm{CF}}=154.2 \mathrm{~Hz}, \mathrm{OCF}_{3}\right), 120.5\left(\mathrm{C}-3^{\prime}\right.$ and $\left.\mathrm{C}-5^{\prime}\right), 121.7\left(\mathrm{~d},{ }^{3} J_{\mathrm{CF}}=\right.$ $7.4 \mathrm{~Hz}, \mathrm{C}-2^{\prime \prime}$ and C-6 $\left.{ }^{\prime \prime}\right), 129.8\left(\mathrm{C}-2^{\prime}\right.$ and C-6 $\left.{ }^{\prime}\right), 135.8\left(\mathrm{C}-1^{\prime}\right), 136.1$ $\left(\mathrm{d},{ }^{4} J_{\mathrm{CF}}=2.2 \mathrm{~Hz}, \mathrm{C}-1^{\prime \prime}\right), 150.6\left(\mathrm{q},{ }^{3} J_{\mathrm{CF}}=1.5 \mathrm{~Hz}, \mathrm{C}-4^{\prime}\right), 157.5(\mathrm{~d}$, ${ }^{1} J_{\mathrm{CF}}=239.0 \mathrm{~Hz}, \mathrm{C}-4^{\prime \prime}$ ), 164.5 (C-4), 167.1 (C-6), 169.0 (C-2). Anal. 
calcd for $\mathrm{C}_{16} \mathrm{H}_{11} \mathrm{~F}_{4} \mathrm{~N}_{5} \mathrm{O}$ : C, 52.61; H, 3.04; N, 19.17. Found: C, 52.55; H, 3.21; N, 18.98 .

\section{6-(4-(Benzyloxy)phenyl)- $N^{2}$-(4-fluorophenyl)-1,3,5-triazine-2,4- diamine (111)}

Yield $0.53 \mathrm{~g}, 55 \%$. Mp $177-179{ }^{\circ} \mathrm{C}(\mathrm{EtOH}) .{ }^{1} \mathrm{H}$ NMR $(300 \mathrm{MHz}$, DMSO- $\left.d_{6}\right): \delta 5.19\left(2 \mathrm{H}, \mathrm{s}, \mathrm{CH}_{2}\right), 7.07\left(2 \mathrm{H}, \mathrm{brs}, \mathrm{NH}_{2}\right), 7.12-7.18$ ( $4 \mathrm{H}, \mathrm{m}, \mathrm{H}-3^{\prime}, \mathrm{H}-5^{\prime}, \mathrm{H}-3^{\prime \prime}$ and $\mathrm{H}-5^{\prime \prime}$ ), 7.35-7.50 (5H, m, Ph), 7.86 $\left(2 \mathrm{H}, \mathrm{dd},{ }^{4} J_{\mathrm{HF}}=5.0 \mathrm{~Hz},{ }^{3} J_{\mathrm{HH}}=9.1 \mathrm{~Hz}, \mathrm{H}-2^{\prime \prime}\right.$ and $\left.\mathrm{H}-6^{\prime \prime}\right), 8.29(2 \mathrm{H}$, $\mathrm{d}, J=8.9 \mathrm{~Hz}, \mathrm{H}-2^{\prime}$ and $\left.\mathrm{H}-6^{\prime}\right), 9.52(1 \mathrm{H}, \mathrm{s}, \mathrm{NH}) ;{ }^{13} \mathrm{C} \mathrm{NMR}(75 \mathrm{MHz}$, DMSO- $\left.d_{6}\right): \delta 69.3\left(\mathrm{CH}_{2}\right), 114.4\left(\mathrm{C}-3^{\prime}\right.$ and C-5 $\left.{ }^{\prime}\right), 114.8\left(\mathrm{~d},{ }^{2} J_{\mathrm{CF}}=\right.$ $22.3 \mathrm{~Hz}, \mathrm{C}-3^{\prime \prime}$ and C-5"), 121.5 (d, ${ }^{3} J_{\mathrm{CF}}=7.4 \mathrm{~Hz}, \mathrm{C}-2^{\prime \prime}$ and C-6" $)$, $127.7\left(\mathrm{C}-2^{\prime \prime \prime}\right.$ and C-6 $\left.{ }^{\prime \prime \prime}\right), 127.9\left(\mathrm{C}-4^{\prime \prime \prime}\right), 128.4\left(\mathrm{C}-3^{\prime \prime \prime}\right.$ and $\left.\mathrm{C}-5^{\prime \prime \prime}\right)$, $129.2\left(\mathrm{C}-1^{\prime}\right), 129.5\left(\mathrm{C}-2^{\prime}\right.$ and $\left.\mathrm{C}-6^{\prime}\right), 136.4\left(\mathrm{~d},{ }^{4} J_{\mathrm{CF}}=2.2 \mathrm{~Hz}, \mathrm{C}-1^{\prime \prime}\right)$, $136.7\left(\mathrm{C}-1^{\prime \prime \prime}\right), 157.3\left(\mathrm{~d},{ }^{1} J_{\mathrm{CF}}=238.5 \mathrm{~Hz}, \mathrm{C}-4^{\prime \prime}\right) 161.0\left(\mathrm{C}-4^{\prime}\right), 164.4$ (C-4), 167.0 (C-6), 169.8 (C-2). Anal. calcd for $\mathrm{C}_{22} \mathrm{H}_{18} \mathrm{FN}_{5} \mathrm{O}: \mathrm{C}$, 68.21; H, 4.68; N, 18.08. Found: C, 68.08; H, 4.80; N, 17.96.

\section{$N^{2}$-(2-Fluorophenyl)-6-(thiophen-2-yl)-1,3,5-triazine-2,4- diamine (116)}

Yield $0.32 \mathrm{~g}, 45 \%$. Mp $165-167{ }^{\circ} \mathrm{C}\left(\mathrm{EtOH} / \mathrm{H}_{2} \mathrm{O}\right) .{ }^{1} \mathrm{H}$ NMR $(300$ MHz, DMSO- $d_{6}$ ): $\delta 7.09$ (2H, brs, $\left.\mathrm{NH}_{2}\right), 7.15-7.27$ (4H, m, H-4', $\mathrm{H}-3^{\prime \prime}, \mathrm{H}-4^{\prime \prime}$ and $\left.\mathrm{H}-5^{\prime \prime}\right), 7.72-7.78\left(2 \mathrm{H}, \mathrm{m}, \mathrm{H}-5^{\prime}\right.$ and $\left.\mathrm{H}-6^{\prime \prime}\right), 7.87$ $\left(1 \mathrm{H}, \mathrm{dd}, J=1.1 \mathrm{~Hz}, J=3.6 \mathrm{~Hz}, \mathrm{H}-3^{\prime}\right), 9.04(1 \mathrm{H}, \mathrm{s}, \mathrm{NH}) ;{ }^{13} \mathrm{C} \mathrm{NMR}$ (75 MHz, DMSO- $d_{6}$ ): $\delta 115.5\left(\mathrm{~d},{ }^{2} J_{\mathrm{CF}}=19.4 \mathrm{~Hz}, \mathrm{C}-3^{\prime \prime}\right), 124.0(\mathrm{~d}$, $\left.{ }^{3} J_{\mathrm{CF}}=3.7 \mathrm{~Hz}, \mathrm{C}-6^{\prime \prime}\right), 125.5\left(\mathrm{~d},{ }^{3} J_{\mathrm{CF}}=7.6 \mathrm{~Hz}, \mathrm{C}-4^{\prime \prime}\right), 126.5\left(\mathrm{~d},{ }^{2} J_{\mathrm{CF}}=\right.$ $\left.11.9 \mathrm{~Hz}, \mathrm{C}-1^{\prime \prime}\right), 126.6\left(\mathrm{~d},{ }^{4} J_{\mathrm{CF}}=2.2 \mathrm{~Hz}, \mathrm{C}-5^{\prime \prime}\right), 128.0\left(\mathrm{C}-4^{\prime}\right), 129.2$ $\left(\mathrm{C}-5^{\prime}\right), 130.9\left(\mathrm{C}-3^{\prime}\right), 142.4\left(\mathrm{C}-1^{\prime}\right), 155.4\left(\mathrm{~d},{ }^{1} J_{\mathrm{CF}}=246.3 \mathrm{~Hz}, \mathrm{C}-2^{\prime \prime}\right)$, 164.8 (C-4), 166.6 (C-6), 166.9 (C-2). Anal. calcd for $\mathrm{C}_{13} \mathrm{H}_{10} \mathrm{FN}_{5} \mathrm{~S}$ : C, 54.35; H, 3.51; N, 24.38. Found: C, 54.22; H, 3.75; N, 24.26.

\section{$N^{2}$-(2-Methoxyphenyl)-6-(thiophen-2-yl)-1,3,5-triazine-2,4- diamine (122)}

Yield $0.43 \mathrm{~g}, 58 \%$. Mp 165-167 ${ }^{\circ} \mathrm{C}(\mathrm{MeCN}) .{ }^{1} \mathrm{H}$ NMR $(300 \mathrm{MHz}$, DMSO- $\left.d_{6}\right): \delta 3.87\left(3 \mathrm{H}, \mathrm{s}, \mathrm{OCH}_{3}\right), 6.94-7.00\left(1 \mathrm{H}, \mathrm{m}, \mathrm{H}-3^{\prime \prime}\right), 7.04-$ $7.08\left(2 \mathrm{H}, \mathrm{m}, \mathrm{H}-4^{\prime \prime}\right.$ and $\left.\mathrm{H}-5^{\prime \prime}\right), 7.18\left(2 \mathrm{H}, \mathrm{brs}, \mathrm{NH}_{2}\right), 7.21(1 \mathrm{H}, \mathrm{dd}, J$ $\left.=3.7 \mathrm{~Hz}, J=5.0 \mathrm{~Hz}, \mathrm{H}-4^{\prime}\right), 7.77\left(1 \mathrm{H}, \mathrm{dd}, J=1.2 \mathrm{~Hz}, J=5.0 \mathrm{~Hz}, \mathrm{H}^{-}\right.$ $\left.5^{\prime}\right), 7.92\left(1 \mathrm{H}, \mathrm{dd}, J=1.3 \mathrm{~Hz}, J=3.7 \mathrm{~Hz}, \mathrm{H}-3^{\prime}\right), 7.97(1 \mathrm{H}, \mathrm{s}, \mathrm{NH})$, 8.21 (1H, d, $\left.J=7.3 \mathrm{~Hz}, \mathrm{H}-6{ }^{\prime \prime}\right) ;{ }^{13} \mathrm{C}$ NMR (75 MHz, DMSO- $d_{6}$ ): $\delta 55.7\left(\mathrm{OCH}_{3}\right), 110.9\left(\mathrm{C}-3^{\prime \prime}\right), 120.3\left(\mathrm{C}-5^{\prime \prime}\right), 121.8\left(\mathrm{C}-6^{\prime \prime}\right), 123.5(\mathrm{C}-$ $\left.4^{\prime \prime}\right), 127.7\left(\mathrm{C}-1^{\prime \prime}\right), 128.1\left(\mathrm{C}-4^{\prime}\right), 129.3\left(\mathrm{C}-5^{\prime}\right), 131.0\left(\mathrm{C}-3^{\prime}\right), 142.3(\mathrm{C}-$ $\left.1^{\prime}\right), 149.6\left(\mathrm{C}-2^{\prime \prime}\right), 164.2$ (C-4), 166.6 (C-6), 166.9 (C-2). Anal. calcd for $\mathrm{C}_{14} \mathrm{H}_{13} \mathrm{~N}_{5} \mathrm{OS}$ : C, 56.17; H, 4.38; N, 23.40. Found: C, 56.08; H, $4.50 ; \mathrm{N}, 23.26$.

\section{$N^{2}$-(4-Methoxyphenyl)-6-(thiophen-2-yl)-1,3,5-triazine-2,4-} diamine (123)

Yield $0.52 \mathrm{~g}, 70 \%$. Mp $139-141{ }^{\circ} \mathrm{C}\left(\mathrm{EtOH} / \mathrm{H}_{2} \mathrm{O}\right) .{ }^{1} \mathrm{H}$ NMR $(300$ MHz, DMSO- $\left.d_{6}\right): \delta 3.74\left(3 \mathrm{H}, \mathrm{s}, \mathrm{OCH}_{3}\right), 6.88(2 \mathrm{H}, \mathrm{d}, J=9.0 \mathrm{~Hz}, \mathrm{H}-$ $3^{\prime \prime}$ and $\left.\mathrm{H}-5^{\prime \prime}\right), 7.06\left(2 \mathrm{H}\right.$, brs, $\left.\mathrm{NH}_{2}\right), 7.20(1 \mathrm{H}, \mathrm{dd}, J=3.7 \mathrm{~Hz}, J=$ $\left.5.0 \mathrm{~Hz}, \mathrm{H}-4^{\prime}\right), 7.70\left(2 \mathrm{H}, \mathrm{d}, J=9.1 \mathrm{~Hz}, \mathrm{H}-2^{\prime \prime}\right.$ and $\left.\mathrm{H}-6^{\prime \prime}\right), 7.76(1 \mathrm{H}$, $\left.\mathrm{dd}, J=1.3 \mathrm{~Hz}, J=5.0 \mathrm{~Hz}, \mathrm{H}-5^{\prime}\right), 7.89(1 \mathrm{H}, \mathrm{dd}, J=1.3 \mathrm{~Hz}, J=$ $\left.3.7 \mathrm{~Hz}, \mathrm{H}-3^{\prime}\right), 9.35$ (1H, s, NH); ${ }^{13} \mathrm{C}$ NMR (75 MHz, DMSO- $d_{6}$ ): $\delta 55.1\left(\mathrm{OCH}_{3}\right), 113.5\left(\mathrm{C}-3^{\prime \prime}\right.$ and $\left.\mathrm{C}-5^{\prime \prime}\right), 121.6\left(\mathrm{C}-2^{\prime \prime}\right.$ and $\left.\mathrm{C}-6^{\prime \prime}\right), 128.0$

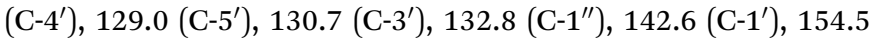

(C-4"), 164.0 (C-4), 166.3 (C-6), 166.7 (C-2). Anal. calcd for $\mathrm{C}_{14} \mathrm{H}_{13} \mathrm{~N}_{5} \mathrm{OS}$ : C, 56.17; H, 4.38; N, 23.40. Found: C, 56.05; H, $4.54 ; \mathrm{N}, 23.23$.

\section{Cytotoxicity evaluation}

The cytotoxic activity of $6, N^{2}$-diaryl-1,3,5-triazine-2,4-diamines (1-126) was evaluated against three breast carcinoma cell lines (MDA-MB231, SKBR-3, and MCF-7) and normal breast cell line (MCF-10A) by MTT assay. ${ }^{22}$ All cells were obtained from the American Type Culture Collection and were grown in $10 \%$ fetal bovine serum and 1\% pen-strep antibiotic supplemented media (DMEM for MDA-MB231 and SKBR-3, RPMI for MCF-7, and MEGM for MCF-10A). For MTT assay, 20000 to 75000 cells per $\mathrm{mL}$ (based on the doubling time for each cell line) were seeded in 96 well plates and incubated for $24 \mathrm{~h}$ at $37^{\circ} \mathrm{C}$ in $5 \%$ $\mathrm{CO}_{2}$ incubator. Then, compounds at different concentrations were added followed by the incubation at $37{ }^{\circ} \mathrm{C}$ for $72 \mathrm{~h}$. After that, MTT solution $\left(0.5 \mathrm{mg} \mathrm{mL} \mathrm{mL}^{-1}\right)$ was added and the plates were incubated for another $4 \mathrm{~h}$. The supernatant was then discarded and $100 \mu \mathrm{L}$ of DMSO was added to each well. The plates were then read by Tecan NanoQuant (model: infinite $\mathrm{m} 200$ pro) plate reader and absorbance was measured at $570 \mathrm{~nm}$. GI $_{50}$ values were calculated using sigmoidal concentration-response curves (see ESI $\dagger$ ) generated using the GraphPad Prism 7 program. Three independent experiments were carried out and the data were represented as mean of the three experiments.

\section{Building 3D-QSAR model}

Out of 25 compounds, 19 compounds were utilized as a training set for building QSAR model. To assess reliability of the prepared model, an external validation was performed using remaining 6 compounds as a test set. The compounds were randomly divided into training and test set via 'Generate training and test set' module in Discover Studio v18. The selected test set included compounds 58, 73, 78, 99, 101, and 120.

For the model construction, the $\mathrm{GI}_{50}$ values of the compounds on MDA-MB231 were converted to the negative logarithmic scale $\left(\mathrm{pGI}_{50}\right)$. The compounds were aligned to the minimum energy using the 'Align small molecules' protocol in the Discovery Studio. Steric (50\%) and electrostatic (50\%) fields were used to align the compounds.

In Discovery Studio, the CHARMm force field was used and the electrostatic potential and the van der Waals potential were treated as separate terms. $\mathrm{A}+1 e$ point charge was used as the electrostatic potential probe and distance-dependent dielectric constant was used to mimic the solvation effect. For the van der Waals potential, a carbon atom with a $1.5 \AA$ radius was used as a probe. The truncation for both the steric and electrostatic energies was set to $30 \mathrm{kcal} \mathrm{mol}^{-1}$. The standard parameters implemented in Discovery Studio v18 were used. A Partial LeastSquare (PLS) model was built using energy grids as descriptors. The QSAR model was built using the created 3D-QSAR protocol of Discovery Studio v18. 


\section{Conflicts of interest}

There are no conflicts to declare.

\section{Acknowledgements}

This work is supported by the Ministry of Higher Education, Malaysia under the Fundamental Research Grant Scheme, grant number FRGS/1/2018/STG01/MUSM/02/2. The work is also partially supported by the Bridging Grant from the School of Pharmacy, Monash University Malaysia.

\section{References}

1 P. Singla, V. Luxami and K. Paul, Triazine as a promising scaffold for its versatile biological behavior, Eur. J. Med. Chem., 2015, 102, 39-57.

2 S. Cascioferro, B. Parrino, V. Spano, A. Carbone, A. Montalbano, P. Barraja, P. Diana and G. Cirrincione, 1,3,5-Triazines: a promising scaffold for anticancer drugs development, Eur. J. Med. Chem., 2017, 142, 523-549.

3 J. H. Silverberg and W. Dameshek, Use of triethylene melamine in treatment of leukemia and leukosarcoma, JAMA, 1952, 148, 1015-1021.

4 J. R. Walsh, P. T. Pratt, W. E. Graham and H. J. Zimmerman, Treatment of leukemia and lymphomata with triethylene melamine, Acta Haematol., 1954, 11, 329-338.

5 P. G. Dyment, D. J. Fernbach and W. W. Sutow, Hexamethylmelamine (NSC-13875) for acute leukemia and solid tumors in children, J. Clin. Pharmacol. New Drugs, 1973, 13, 111-113.

6 M. Karon, L. Sieger, S. Leimbrock, J. Z. Finklestein, M. E. Nesbit and J. J. Swaney, 5-Azacytidine: a new active agent for the treatment of acute leukemia, Blood, 1973, 42, 359-365.

7 A. Aribi, G. Borthakur, F. Ravandi, J. Shan, J. Davisson, J. Cortes and H. Kantarjian, Activity of decitabine, a hypomethylating agent, in chronic myelomonocytic leukemia, Cancer, 2007, 109, 713-717.

8 E. Jabbour, J.-P. Issa, G. Garcia-Manero and H. Kantarjian, Evolution of decitabine development: accomplishments, ongoing investigations, and future strategies, Cancer, 2008, 112, 2341-2351.

9 E. S. Kim, Enasidenib: First global approval, Drugs, 2017, 77, 1705-1711.

10 E. M. Stein, Enasidenib, a targeted inhibitor of mutant IDH2 proteins for treatment of relapsed or refractory acute myeloid leukemia, Future Oncol., 2018, 14, 23-40.

11 A. M. Venkatesan, C. M. Dehnhardt, E. Delos Santos, Z. Chen, O. Dos Santos, S. Ayral-Kaloustian, G. Khafizova, N. Brooijmans, R. Mallon, I. Hollander, L. Feldberg, J. Lucas, K. Yu, J. Gibbons, R. T. Abraham, I. Chaudhary and T. S. Mansour, Bis(morpholino-1,3,5-triazine) Derivatives: Potent Adenosine 5'-Triphosphate Competitive Phosphatidylinositol-3-kinase/Mammalian Target of Rapamycin Inhibitors: Discovery of Compound 26 (PKI587), a Highly Efficacious Dual Inhibitor, J. Med. Chem., 2010, 53, 2636-2645.

12 M. Robert, R. F. Larry, L. Judy, C. Inder, D. Christoph, D. S. Efren, C. Zecheng, D. S. Osvaldo, A. K. Semiramis, V. Aranapakam and H. Irwin, Antitumor efficacy of PKI587, a highly potent dual PI3K/mTOR kinase inhibitor, Clin. Cancer Res., 2011, 17, 3193-3203.

13 B. J. Rhy, S. Kim, B. Min, K. Y. Kim, J. S. Lee, W. J. Park, H. Lee, S. H. Kim and S. Y. Park, Discovery and the structural basis of a novel p21-activated kinase 4 inhibitor, Cancer Lett., 2014, 349, 45-50.

14 M. Koh, J. C. Lee, C. Min and A. Moon, A novel metformin derivative, HL010183, inhibited proliferation and invasion of triple negative breast cancer cells, Bioorg. Med. Chem., 2013, 8, 2305-2313.

15 G. Miao, B. Liu, X. Guo, X. Zhang and G. Liu, Reduction behavior induced by HL010183, a metformin derivative against the growth of cutaneous squamous cell carcinoma, Int. J. Clin. Exp. Pathol., 2015, 1, 287-297.

16 A. Junaid, F. P. L. Lim, E. R. T. Tiekink and A. V. Dolzhenko, New one-pot synthesis of 1,3,5-triazines: three-component condensation, Dimroth rearrangement and dehydrogenative aromatization, ACS Comb. Sci., 2019, 21, 548-555.

17 A. Junaid and A. V. Dolzhenko, Microwave-assisted synthesis of 1,3,5-triazines: efficient approaches to therapeutically valuable scaffold, Heterocycles, 2019, 98, 1678-1706.

18 D. L. Holliday and V. Speirs, Choosing the right cell line for breast cancer research, Breast Cancer Res., 2011, 4, 215.

19 Discovery Studio Modeling Environment, Biovia DS, Dassault Systems, San Diego, 2017.

20 M. Awasthi, S. Singh, V. P. Pandey and U. N. Dwivedi, Molecular docking and 3D-QSAR-based virtual screening of flavonoids as potential aromatase inhibitors against estrogen-dependent breast cancer, J. Biomol. Struct. Dyn., 2015, 33, 804-819.

21 B. Yang, Y. S. Yang, N. Yang, G. Li and H. L. Zhu, Design, biological evaluation and 3D QSAR studies of novel dioxincontaining pyrazoline derivatives with thiourea skeleton as selective HER-2 inhibitors, Sci. Rep., 2016, 6, 27571.

22 D. A. Scudiero, R. H. Shoemaker, K. D. Paull, A. Monks, S. Tierney, T. H. Nofziger, M. J. Currens, D. Seniff and M. R. Boyd, Evaluation of a Soluble Tetrazolium/formazan Assay for Cell Growth and Drug Sensitivity in Culture Using Human and Other Tumor Cell Lines, Cancer Res., 1988, 48, 4827-4833. 